\title{
"Canção do Poeta do Século XVIII", de Heitor Villa-Lobos: identidade transitiva no repertório villalobiano para canto e violão
}

Humberto Amorim

Universidade Federal do Rio de Janeiro (UFRJ) humbertoamorim@musica.ufr.jbr 


\section{Resumo}

A partir do levantamento de dados, datas de estreias, entrevistas, primeiras interpretações, gravações e críticas, além de mais de 30 matérias suscitadas em jornais e periódicos, este artigo apresenta dois propósitos: primeiro, realizar uma genealogia das três versões concebidas por Villa-Lobos para uma de suas peças vocais ainda pouco conhecida, a "Canção do Poeta do Século XVIII"; depois, avaliar se (e em que medida) o debate em torno de questões estéticas e/ou estilísticas esteve presente já nos primeiros registros (gravações e performances) e críticas musicais que a obra recebeu ao longo das décadas de 1960 e 1970. Os resultados suscitam um possível olhar sobre a produção para canto e violão de Villa-Lobos a partir do conceito de "identidade transitiva", proposto por Llanos (2018).

Palavras-chave: Canção do Poeta do Século XVIII. Heitor Villa-Lobos. Canto e violão. "Identidade transitiva".

\section{Abstract}

With the gathering of data, premiere dates, interviews, first performances, recordings and critiques, as well as more than 30 unpublished articles in newspapers and periodicals, this article has two purposes: first, to make a genealogy of the three versions devised by Villa-Lobos for one of his still little known vocal pieces, the Song of an Eighteenth Century Poet; then, to assess whether the debate around aesthetic and/or stylistic issues was already present in the early records, performances and musical critiques that the work received throughout the 1960s and 1970s. The results raise a possible look at Villa-Lobos's production for voice and guitar from the concept of "transitive identity" proposed by Llanos (2018).

Keywords: Song of an Eighteenth Century Poet. Heitor Villa-Lobos. Voice and guitar. Guitar and National Identity. 


\section{Introdução}

Nas últimas duas décadas, importantes estudos (LLANOS, 2018; TABORDA, 2011; PEREIRA, 2007) vêm paulatinamente ratificando a ideia de que a síntese em torno do que chamamos de "violão brasileiro" se deu no esteio de uma cadeia rizomática (DELEUZE; GUATTARI, 2000), ou seja, de forma heterogênea, sem um centro predominante e com os seus variados elementos se atravessando e se influenciando reciprocamente em uma genealogia de "pergaminhos embaralhados" (FOUCAULT, 2005 [1971], p. 261) ${ }^{1}$.

Diante desta gênese "cinzenta", as distinções entre "erudito" e "popular" passariam a ter um sentido menor, uma vez que ambas as tradições se cruzam e se tornam, por vezes, indissociáveis, em uma "identidade transitiva" que "ora admite e ora exige diversos complementos para o exercício de seu sentido semântico" (LLANOS, 2018, p. 96).

"Tupi, or not Tupi that is the question."2 O violão no Brasil parece ter desdobrado a proposição antropofágica de Oswald de Andrade para Tupi and not Tupi, uma força capaz de se articular por entre esta zona de espaços transitivos: "Temos a base dupla e presente - a floresta e a escola. A raça crédula e dualista e a geometria, a álgebra e a química logo depois da mamadeira e do chá de erva-doce. Um misto de 'dorme nenê que o bicho vem pegá' e de equações". (ANDRADE, 1976, [s.p.])

Se diferentes matrizes culturais constituem indissoluvelmente o arcabouço do que chamamos de "violão brasileiro", torna-se necessário tentar vislumbrar de que maneiras esta leitura-escrita difusa reverberou na produção de nossos(as) compositores(as) e intérpretes. Neste sentido, Heitor Villa-Lobos (1887-1959) talvez tenha sido o personagem mais decisivo no movimento (sempre contínuo e plástico) de fundamentar - pela síntese - as bases potenciais do instrumento no Brasil.

O papel dos intérpretes e a recepção crítica das obras também são aspectos relevantes neste processo, uma vez que a obra de Villa-Lobos para o instrumento se articula e se desdobra, muitas vezes, a partir da inventividade de músicos que transitaram (e transitam), sem rodeios ou pudores, entre os saberes-fazeres musicais que escapam às margens estreitas das definições compartimentadas. Com cinco peças ${ }^{3}$ transcritas e/ ou reduzidas de outras formações pelo próprio compositor, sua produção camerística para canto e violão se alimenta nesta manjedoura, no âmbito de uma teia cultural que "oferece ao indivíduo um horizonte de possibilidades latentes - uma jaula flexível e invisível dentro da qual se exercita a liberdade condicionada de cada um" (GINZBURG, 1987, p. 27).

A partir do levantamento de dados, datas de estreias, entrevistas, primeiras interpretações e gravações, além de mais de 30 matérias suscitadas em jornais e periódicos,

\footnotetext{
1 "A genealogia é cinzenta: ela é meticulosa e pacientemente documentária. Trabalha com pergaminhos embaralhados, riscados, muitas vezes reescritos" (FOUCAULT, 2005 [1971], p. 261).

2 Excerto do "Manifesto da Poesia Pau-Brasil", publicado originalmente por Oswald de Andrade (1890-1954) na edição do jornal Correio da Manhã de 18 de março de 1924.

3 Modinha (a $5^{a}$ da série das 14 Serestas), Ária das Bachianas Brasileiras nº 5, Canção do Poeta do Século XVIII, Canção do Amor e, finalmente, Veleiros, esta última para voz e dois violões.
} 
este artigo apresenta dois propósitos: primeiro, realizar uma genealogia das três versões concebidas por Villa-Lobos para uma de suas peças vocais ainda pouco conhecida, a "Canção do Poeta do Século XVIII"; depois, avaliar se (e em que medida) este debate em torno do eventual caráter transitivo da produção do compositor esteve presente nos primeiros registros (gravações e performances) e críticas musicais que a obra recebeu ao longo das décadas de 1960 e 1970.

\section{Versão de "Canção do Poeta do Século XVIII" para canto e piano (1948)}

Entre as décadas de 1940 e 1950, "Canção do Poeta do Século XVIII" foi concebida por Heitor Villa-Lobos (1887-1959) em três diferentes versões. A primeira delas, para canto e piano, data oficialmente de 1948, segundo a data expressa em um dos manuscritos autógrafos pertencentes ao acervo do Museu-Villa Lobos.

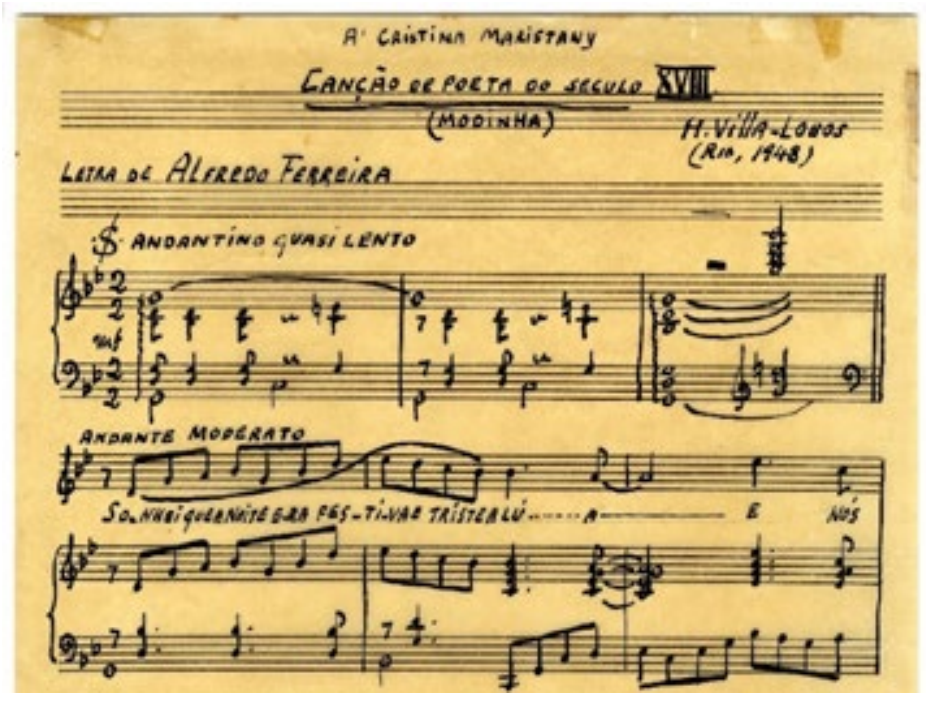

Fig. 1: Autógrafo de "Canção do Poeta do Século XVIII" com a data de composição expressa. Fonte: Museu Villa-Lobos, MVL 1996-21-0013.

Dedicada à soprano luso-brasileira Cristina Maristany (1906-1966) ${ }^{4}$, a versão original foi publicada em 1953 (portanto, cinco anos depois de sua criação) pela Southern Music Publishing Co, com direitos autorais reservados à editora americana Peer Music. A letra é de Alfredo Ferreira, mas, como a peça ganhou suas primeiras edições impressas nos Estados Unidos, uma versão da poesia em inglês também foi assinada por Julian de Gray para atender à demanda do público norte-americano.

4 Cristina Navarro de Andrade Costa nasceu em 11 de agosto de 1906, na cidade do Porto (Portugal), mudando-se com a família, ainda criança, para o Brasil. Assumiu o nome (civil e artístico) de Cristina Maristany após se casar com Breno Maristany, carioca criado no bairro do Méier e antigo professor do Colégio Pedro Il. Foi responsável pela gravação de dezenas de discos a partir da década de 1930, percorrendo diversas cidades europeias e sul-americanas em turnês e se consagrando como uma das mais significativas vozes do canto brasileiro entre as décadas de 1930 e 1960. De Villa-Lobos, recebeu dedicatórias e/ou estreou algumas de suas obras vocais (são exemplos: Canções de Cordialidade [1945]; Duas Paisagens [1946]; Magdalena [1947]; Sete Vezes [1958], dentre outras), tornando-se uma das suas mais representativas intérpretes. Faleceu no dia 27 de setembro de 1966, em Rio Claro (SP), aos 60 anos de idade. 
Na última edição do catálogo de obras do compositor publicada pelo Museu Villa-Lobos (Villa-Lobos - Sua Obra, 2009) não consta quando eventualmente ocorreram as primeiras audições da obra, informação que é dada toda vez que se há notícias das performances. De fato, não encontramos registros de execuções públicas nos anos imediatamente posteriores à sua concepção, mas, através do levantamento nos periódicos brasileiros da década de 1950, constatamos que o primeiro recital coberto pela imprensa a incluir a peça no programa ocorreu em uma quinta-feira, 8 de agosto de 1957, ocasião em que a Associação Brasileira de Imprensa (ABI), em seu famoso auditório Oscar Guanabarino, promoveu um concerto em homenagem aos 70 anos do compositor.

Com uma plateia ilustre e contando com a presença de Villa-Lobos e Mindinha, o comemorativo "recital de composições de canto" foi noticiado em pelo menos três jornais: A Noite (1957a); Correio da Manhã (1957) e o Boletim da Associação Brasileira de Imprensa (1957). Dentre as homenagens e os números diversos do programa, a "Canção do Poeta do Século XVIII" foi interpretada pela cantora Dircéa de Amorim e pela pianista Leonora Gondim, duo responsável pela quase integralidade do repertório executado na ocasião.

HOMENAGEM A VILLA LOBOS - No, programa de homenagens a Yilla Lobos, pela passagem do seu 70." aniversario natalicio, a As sociação Brasileira de Imprensa realizou sessão solene e recital de composiçōes de canto do ilustre músico. Aberta a sessão pelo presidente da A.B.I., o coral do Conservatorio Na cional de Canto Orfeónico cantou o Hino d Imprensa, de Villa Lobes, com letra de Muri lo Araujo. O nosso companheiro António Garcia de Miranda Neto sáludou o homenageacio em curta oracão, fixando três aspectos dä arte do mestre: Marco Polo, D. Quixote e a rfeu. Depois das valavres do jornalista, a cantora Dircéia de Amorim. com Leonora Gondim ao piano, interpreton deliciosamente os Quatro Epigramas de Ronald de Carvalho, $E$ u te Amo, de Dora Vasconcelos, Trés Serestas. A Cança do Poeta do Seculo XVIII, de Alf redo Ferreiro e a Cantilena das Bachianas Brasileiras n.:5, de Manuel Bandeira. Foi uma excelente e cordial manifestação dos jornalistas brasileiros ao sen grande confrade Villa Lobos, sócio da A.B.I., que acaba de receber no Velho Mundo uma imensa consagração. Na foto, Miranda Netto quando falava.

Fig. 2: Nota sobre o concerto com peças vocais de Heitor Villa-Lobos realizado na Associação Brasileira de Imprensa (ABI). Fonte: A noite (1957b).

O concerto despertou a atenção de alguns críticos. Ainda no jornal A Noite, Hestia Barroso definiu a performance das artistas nos seguintes termos:

[...] Não cabe nesta crônica analisar as características da voz da solista, mesmo porque o fizemos muito recentemente, quando integrou o quarteto de cantores que interpretou a "Missa de Natal", do padre José Maurício, com a O. S. B., sob a regência do maestro Mignone [a crítica foi bastante desfavorável]..$^{5}$

Leonora Gondim demonstrou haver preparado cuidadosamente os acompanhamentos, feitos ao piano. (A NOITE, 1957d).

5 "[...] A 'Missa de Natal', do padre José Maurício, também apresentada em primeira audição, não esteve favorecida entre as produções de Dvorak e Stravinski. Dircéa Amorim - uma das solistas - nos pareceu uma escolha pouco feliz, em virtude da voz trêmula, abalada e de timbre em nada sedutor, contrastando chocantemente com o belo material de que dispõe Maura Moreira. Isauro Camino e Roberto Galeno defenderam a parte das vozes masculinas, tendo ainda a Associação de Canto Coral a responsabilidade da massa das vozes, demonstrando a habitual eficiência" (A NOITE, 1957c, grifo nosso). 
Mais complacente com a cantora, Eurico Nogueira França também deixou impressões sobre o recital em sua coluna musical no Correio da Manhã, depois também replicada no Boletim da Associação Brasileira de Imprensa (1957).

[...] Ateve-se Dircéa de Amorim a um grupo pequeno, mas suficientemente re-
presentativo de canções de Villa Lobos [...]. Deu a cantora, cuja carreira acompa-
nho, há tempos, provas de haver obtido nítidos progressos com sua recente via-
gem de estudos aos Estados Unidos. É sua voz de timbre cativante, de emissão
firme, e a serviço de bastante rica musicalidade. Do seu programa se destacou
a magnífica Ária das Bachianas no 5 , pela cristalina pureza do rendimento vocal,
quer na parte de vocalizes, quer no trecho com palavras. Trata-se, aliás, de uma
obra ilustre do repertório desde que Bidu Sayão pela primeira vez a gravou e em
cuja interpretação Dircéa de Amorim, com Leonora Gondim, ao piano, atingiu
comunicativo relevo. EURICO NOGUEIRA FRANÇA (CORREIO DA MANHÂ, 1957).

São louvores e críticas em torno da apresentação que, desconhecida até o momento, marca a primeira audição no Brasil da "Canção do Poeta do Século XVIII", estreada em um recital de maior importância nove anos depois de concebida.

A versão para canto e piano, contudo, logo ganharia novos(as) intérpretes no Brasil6, a começar pela dedicatária da peça, Cristina Maristany, que a apresentou em novembro de 1960 durante a "Semana da Música dedicada a Heitor Villa-Lobos", evento que ocorreu em Salvador, na Bahia. Com Alceo Bocchino (1918-2013) ao piano, o duo executou um programa inteiramente dedicado a obras vocais de Villa-Lobos "com enorme sucesso", tendo a presença de "um público muito entusiástico, inclusive o Governador [Juracy Magalhães] e diversas personalidades do Estado da Bahia" (JORNAL DO COMMERCIO, 1960). Nas décadas seguintes, a peça ainda integraria o repertório de concerto de cantoras prestigiadas, tais como Maria Helena Buzelin e Magali Borges (TRIBUNA DA IMPRENSA, 1979, 1989).

As primeiras gravações também não tardaram a ocorrer. O pioneirismo ficou a cargo da mineira Maria Helena Sterling. Ladeada pelo pai, o pianista e maestro Francisco Buzelin, a cantora fez o registro no LP Joias do Canto Brasileiro ${ }^{7}$, disco anunciado em 3 de março de 1958 pelo Correio da Manhã (1958). Um dia antes, o mesmo jornal havia publicado uma encomiástica crítica, oferecendo detalhes da atuação profissional de Sterling e classificando o LP como "excelente":

[...] Desconhecida, talvez, do grande público fonográfico - mas sobejamente aplaudida entre os aficionados da música erudita -, dados os seus inúmeros recitais ao microfone da Rádio Nacional, como solista da orquestra do maestro Léo Peracchi, a cantora mineira MARIA HELENA STARLIN estreia auspiciosamente em disco! Pertence ao "cast" da Rádio Ministério da Educação, onde apresenta audições semanais; é portadora de um belíssimo timbre, ótima dicção, força interpretativa do mais elevado estilo. Todas as suas criações, neste LP, estão dentro de um mesmo plano de perfeição artística e técnica. Um lançamento excepcional da Sinter, em 1958, revelando um grande valor ao mundo fonográfico

6 Radicado em São Paulo, o cantor boliviano Carlos René Paulet, por exemplo, incluiu a peça em seu repertório a partir de meados da década de 1970 (DIÁRIO DO PARANÁ, 1973).

7 "SINTER (Selo Grenat [Vermelho]), de 12" [polegadas], nº SLP-1.512, em 33 1/3 R.P.M., vocal com acompanhamento de piano" (CORREIO DA MANHÃ, 1958). 
brasileiro, testemunhando mais uma vez o alto tirocínio profissional do diretor Luiz Bittencourt. Irrepreensível a sonoridade das gravações. Cotação. Excelente. - C. P. (CORREIO DA MANHÃ, 2/3/1958. Fonte: Museu Villa-Lobos - Recorte de Jornais - 42.033.1.i.00).

Poucos dias depois, sem deixar de destacar os méritos da cantora, o periódico 0 Jornal publicou uma crítica mais ponderada, listando nominalmente o repertório e conferindo a cotação de 3 estrelas para a gravação.

Cotação ***. [...] Villa-Lobos, Alberto Nepomuceno, Francisco Mignone, Camargo Guarnieri, Valdemar Henrique comparecem a este LP com belas e inspiradas melodias. [...] Maria Helena é uma autêntica revelação de cantora. Voz doce e melodiosa de mezzo soprano, os diversos "lieds" com categoria e dela é lícito aguardar novas e ainda melhores apresentações.

$\mathrm{O} L P$, tecnicamente, não está perfeito, com a agulha obrigada a saltar alguns sulcos sem querer. Boa a capa com foto de Maria Sterling e muito bom o texto de contracapa, com dados amplos sobre a cantora e cada uma das faixas escoIhidas. (O JORNAL, 1958).

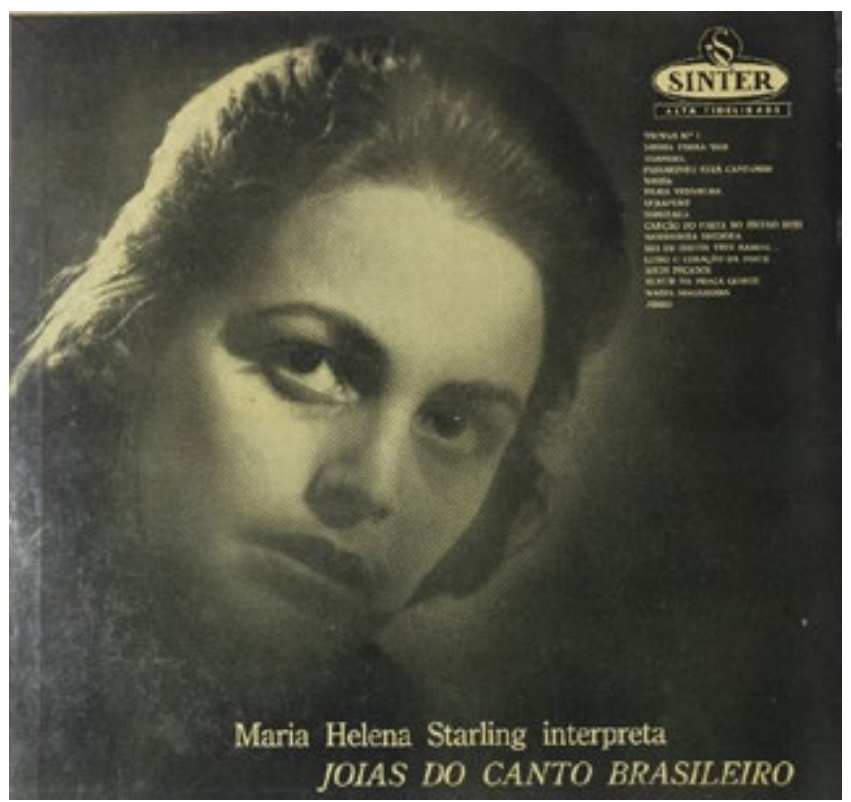

Fig. 3: Capa do LP Joias do Canto Brasileiro, de Maria Helena Starling Fonte: Museu Villa-Lobos - Capas de disco/0905.

Assim como havia ocorrido com as primeiras performances, Cristina Maristany também foi uma das pioneiras no registro fonográfico da obra. Com o maestro Alceo Bocchino ao piano, ela lança o álbum Canções Típicas Brasileiras, em 1964 , com músicas de Roquete Pinto, Mário de Andrade, tradicionais anônimas e, sobretudo, Villa-Lobos. O disco foi relançado em $1978^{9}$, conforme indica o Jornal do Brasil de 9 de março daquele ano (JORNAL DO BRASIL, 1978).

8 Angel/EMI-Odeon, n. de catálogo: 3 CBX-395, 1964.

9 Odeon - SC. 10114/ MEC/ FUNARTE/INM 


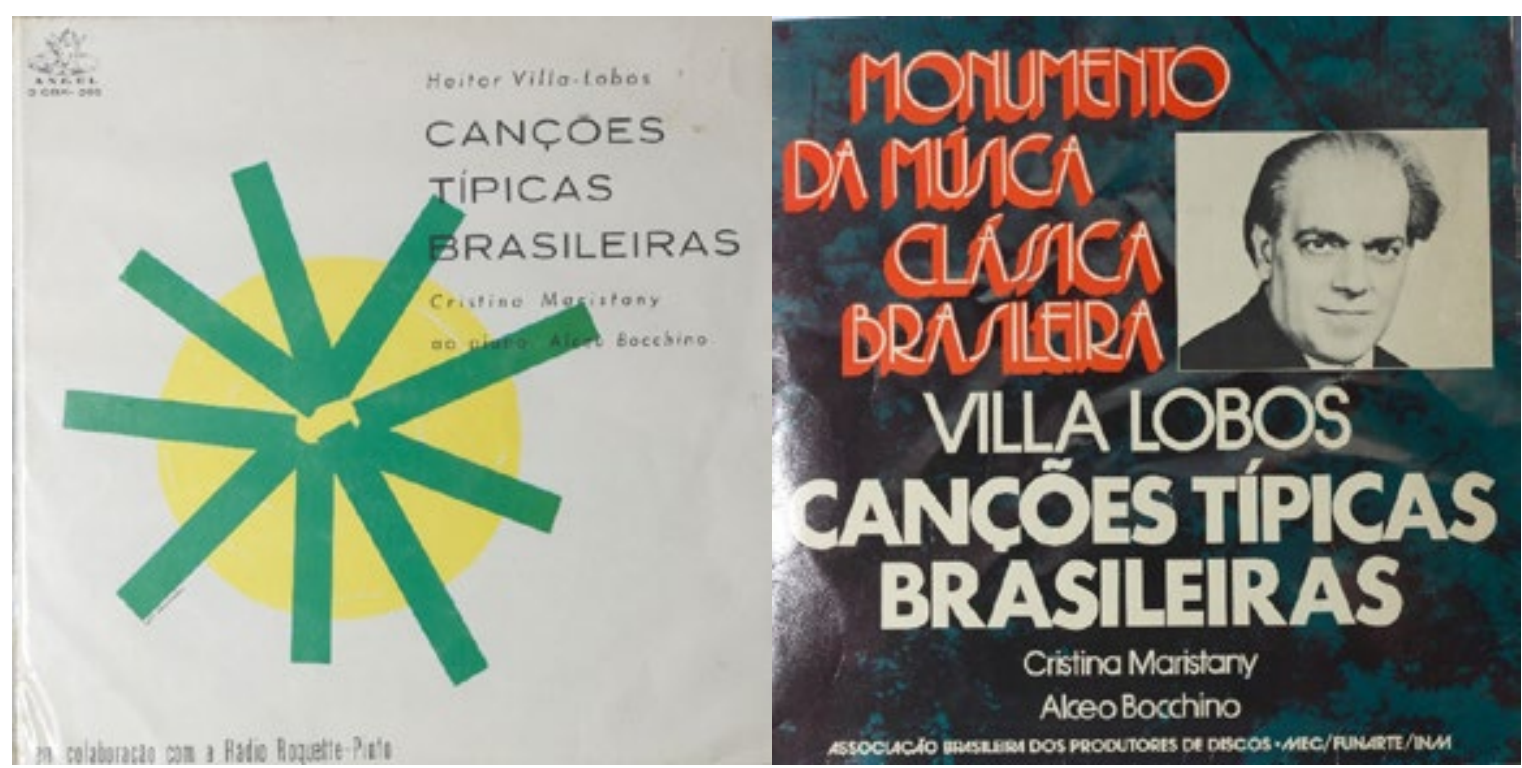

Figs. 4 e 5: Capas dos LPs de Cristina Maristany (voz) e Alceo Bocchino (piano). À esquerda, o de 1964, "em colaboração com a Rádio Roquette Pinto"; à direita, o de 1978, em parceria com a "Associação Brasileira dos Produtores de Discos". Fonte: Museu Villa-Lobos - Capas de disco/ 899 e 900.

Note-se como a escolha dos títulos dos álbuns não são fortuitas: Joias do Canto Brasileiro e Canções Típicas Brasileiras. Os termos empregados, longe de serem neutros, cumprem uma função: o de vincular um caráter de identidade nacional às peças vocais escolhidas. Neste sentido, há uma aproximação no sentido dos termos "canto brasileiro" e "canções brasileiras" com o que usualmente serve ao conceito de "violão brasileiro": um modus operandi capaz de abrigar diferentes matrizes musicais e, a partir desta síntese, projetar sobre a música - tanto na composição quanto na interpretação - um jeito próprio de saber-fazer musical, caracterizado por trocas, imbricamentos e fronteiras movediças.

Além de Sterling e Maristany, outras intérpretes também registraram a versão para canto e piano nas décadas seguintes, incluindo a famosa cantora espanhola Teresa Berganza (1935, 84 anos). Lançado em 1994 pela gravadora suíça Claves Records, este CD teve ao piano o também espanhol Juan Antonio Alvarez Parejo e apresentou Berganza, interpretando seis peças de Villa-Lobos, além de obras de Ernani Braga e do cancioneiro tradicional brasileiro. Na crítica de Carlos Dantas, da Tribuna da Imprensa (1994), os "erros flagrantes" dos dados biográficos e das letras impressas na parte gráfica do álbum só foram mitigados pela inescapável constatação da musicalidade do duo. 


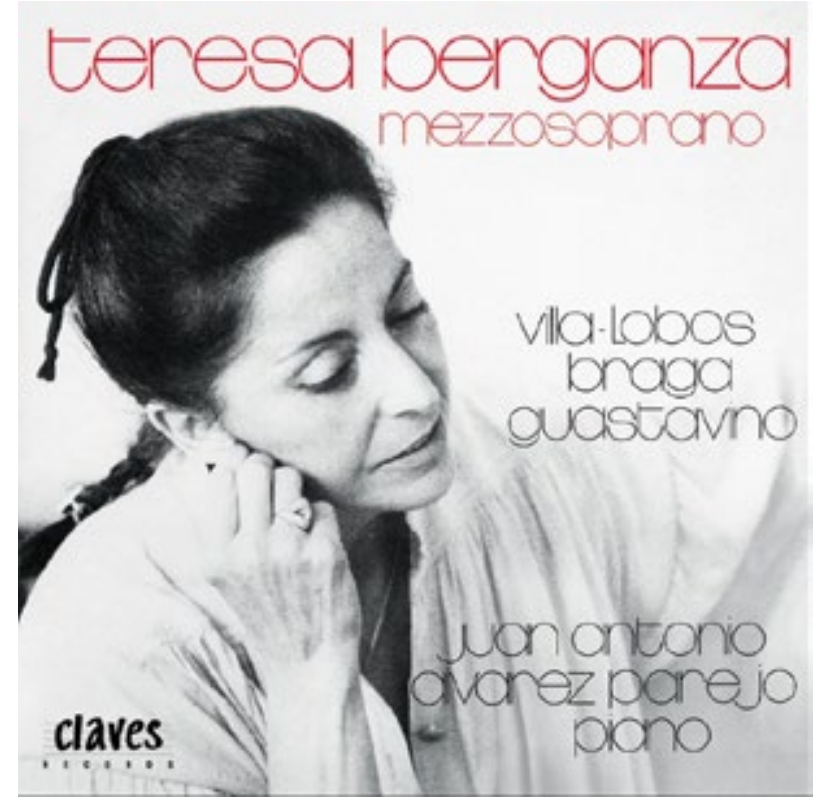

Fig. 6: Capa do CD Teresa Berganza mezzosoprano. Fonte: Claves Records/ acervo pessoal do autor.

Ainda bem que os equívocos da gravadora suiça restringem-se à parte gráfica do compact disc. O conteúdo sonoro aparece isento, liso e livre, mostrando a exuberância vocal de Teresa Berganza, a já lendária espanhola, meio-soprano, num programa só de canções [...]. Há bastante emoção e graça na interpretação de Berganza, a quem o público está mais habituado a ouvir cantando música operística. A pronúncia atesta uma bem aceitável inteligibilidade, naturalmente sem fugir à evidência de que se trata de uma estrangeira cantando no nosso idioma. Berganza e o pianista atuam em regime de real co-interpretação, voz e acompanhamento, dispostos numa linha ideal de equilíbrio sonoro. (TRIBUNA DA IMPRENSA, 1994).

Embora já pontuem aspectos que posteriormente foram tomados como decisivos para classificar uma boa ou má interpretação das canções de Villa-Lobos (como a dicção, a inteligibilidade da letra e a força interpretativa), as críticas em torno destas primeiras audições e gravações ainda não tocam frontalmente as questões estéticas/ estilísticas das obras. Este fator acaba sendo mais sugerido pela escolha dos títulos dos álbuns brasileiros mencionados do que propriamente pela discussão do tema nas páginas dos jornais, um panorama que irá mudar quando nos depararmos com a versão para canto e violão de "Canção do Poeta do Século XVIII".

\section{Versão para canto e orquestra (1959)}

Uma das últimas adaptações realizadas por Villa-Lobos, a versão para canto e orquestra de "Canção do Poeta do Século XVIII", foi escrita em 195910, mesmo ano de falecimento do compositor. Além da voz solista, o bojo orquestral é composto por 2 flautas, 2 clarinetes em Bb, 2 fagotes, 3 cornetas, trombone, tuba, tímpano, harpa e cordas. Nos acervos do Museu Villa-Lobos, há um manuscrito autógrafo de cinco páginas, em papel

10 Segundo consta na $2^{a}$ edição do Catálogo Villa-Lobos, Sua Obra (1972), publicada pelo Museu Villa-Lobos. 
heliográfico, com dimensões de 44 x 31,5 cm. Até o momento, não há publicações impressas da obra.

A estreia desta versão ocorreu em 10 de novembro de 1962, no Theatro Municipal do Rio de Janeiro, durante a abertura da programação do Festival Villa-Lobos daquele ano. Esta apresentação foi amplamente divulgada pela imprensa (DIÁRIO CARIOCA, 1962a, 1962b; A NOITE, 1962; DIÁRIO DE NOTÍCIAS, 1962). Na ocasião, a Orquestra Sinfônica Brasileira (OSB) foi regida por Eleazar de Carvalho (1912-1996), e a solista foi a dedicatária da versão original, Cristina Maristany, também responsável no evento pela primeira audição brasileira de "Eu te Amo" (1956), outra das composições de Villa-Lobos para canto e orquestra. O concerto iniciou às $16 \mathrm{~h} 30$ e contou ainda com outras importantes obras orquestrais do compositor: "Bachianas Brasileiras no 9", "Erosão e Invocação em Defesa da Pátria", além de José Vieira Brandão solando ao piano a "Bachianas Brasileiras no 3".

Sem edições impressas e enfrentando a dificuldade de ser programada no sempre exíguo e disputado repertório das temporadas orquestrais, a versão para canto e orquestra só recebeu novo impulso em 1973, quando o Festival Villa-Lobos a incluiu dentre as obras possíveis de serem interpretadas na prova final de seu famoso concurso internacional de canto. Ainda assim, a peça aparecia diluída entre mais de 20 possibilidades de escolha, dentre as quais despontavam alguns dos maiores standards de Villa-Lobos.

\begin{tabular}{|c|c|}
\hline IUSICA & Renzo Massarani \\
\hline 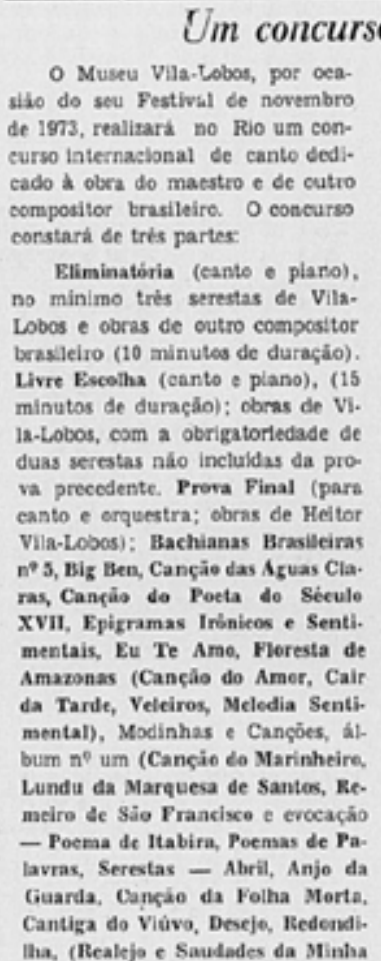 & 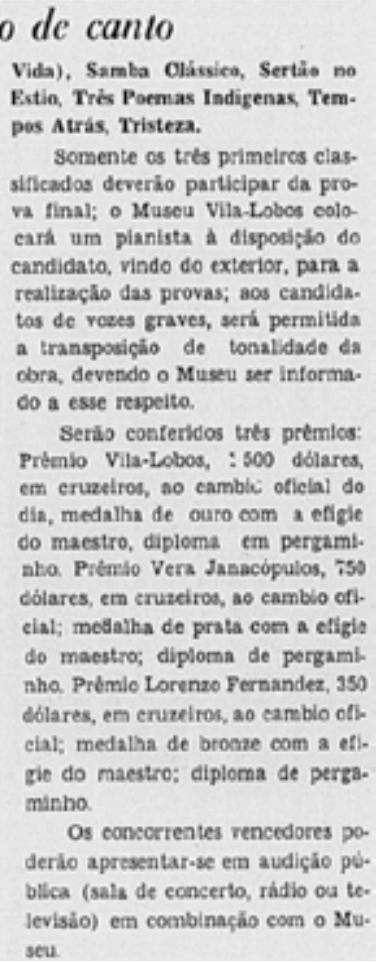 \\
\hline
\end{tabular}

Fig. 7: Nota na coluna Música, de Renzo Massarani. Fonte: Jornal do Brasil (1973a). 
Além de Renzo Massarani, no Jornal do Brasil, a competição foi amplamente pautada por outros críticos: na coluna de D'Or, no Diário de Notícias (1973), houve a publicação da íntegra do regulamento; o Jornal dos Sports (1973) também conferiu grande destaque ao evento em suas páginas; e Carlos Dantas, na Tribuna da Imprensa (1973), apesar das severas críticas ao meio musical carioca e à proliferação dos concursos musicais, não deixa de valorizar o certame "bastante promissor".

\begin{abstract}
Ao meio musical carioca falta tudo. Principalmente administradores. Com as exceções de praxe, a administração da música nesta paróquia só não tem sido um vazio total porque a incompetência e a cretinice costumam fazer enorme volume. Mas as carências do Rio artístico parecem encontrar uma espécie de resgate na abundância, por exemplo, de concursos. Agora mesmo há não sei quantos. Toda biboca, toda casa ligada ao som deu pra promover competições. Daí um pouco da queda de nível verificada nessa soma excessiva de certames. O II Internacional de Piano está aí para provar. Nem primeiro lugar houve.

Enfim, se é o que nos é dado realizar com frequência nesta terra, prestigiaremos os Concursos. Vem um, aliás, bastante promissor. É o Internacional de Canto do Festival Villa-Lobos, promoção do Museu dirigido por Arminda Villa-Lobos. Vai ser em novembro, in memorian do mestre [...]. (TRIBUNA DA IMPRENSA, 1973).
\end{abstract}

Segundo o item 10 do regulamento, apenas as(os) três primeiras(os) classificadas(os) passariam à prova final, quando a versão para canto e orquestra da "Canção do Poeta do Século XVIII" poderia eventualmente ser escolhida. Em meio a peças mais estabelecidas e/ou conhecidas do repertório vocal villalobiano, muito provavelmente $\circ$ incentivo à sua performance ficou apenas no aspecto simbólico, com a inclusão da obra dentre as elegíveis para a finalíssima do certame. Após este evento, não conseguimos resgatar outros registros de que a versão tenha sido programada, no Brasil, nos anos e décadas subsequentes.

\title{
4. Versão para canto e violão (1953): transitividade, primeiros intérpretes e estreia com Jodacil Damaceno e Cristina Maristany
}

No ano de 1953, cinco anos após conceber a versão original para canto e piano (1948), Villa-Lobos reencontra criativamente a "Canção do Poeta do Século XVIII", desta vez com o violão no acompanhamento da voz. Novamente dedicada à cantora Cristina Maristany, não foi possível averiguar os motivos que instigaram o compositor a considerar esta nova versão. Sabe-se, apenas, que ele já havia passado pela experiência dos contatos com a cantora e violonista Olga Praguer Coelho (1909-2008), personagem que antes já o tinha levado a escrever as transcrições da "Ária da Bachianas Brasileiras no 5" e da "Modinha", esta última a quinta na série das catorze Serestas. 


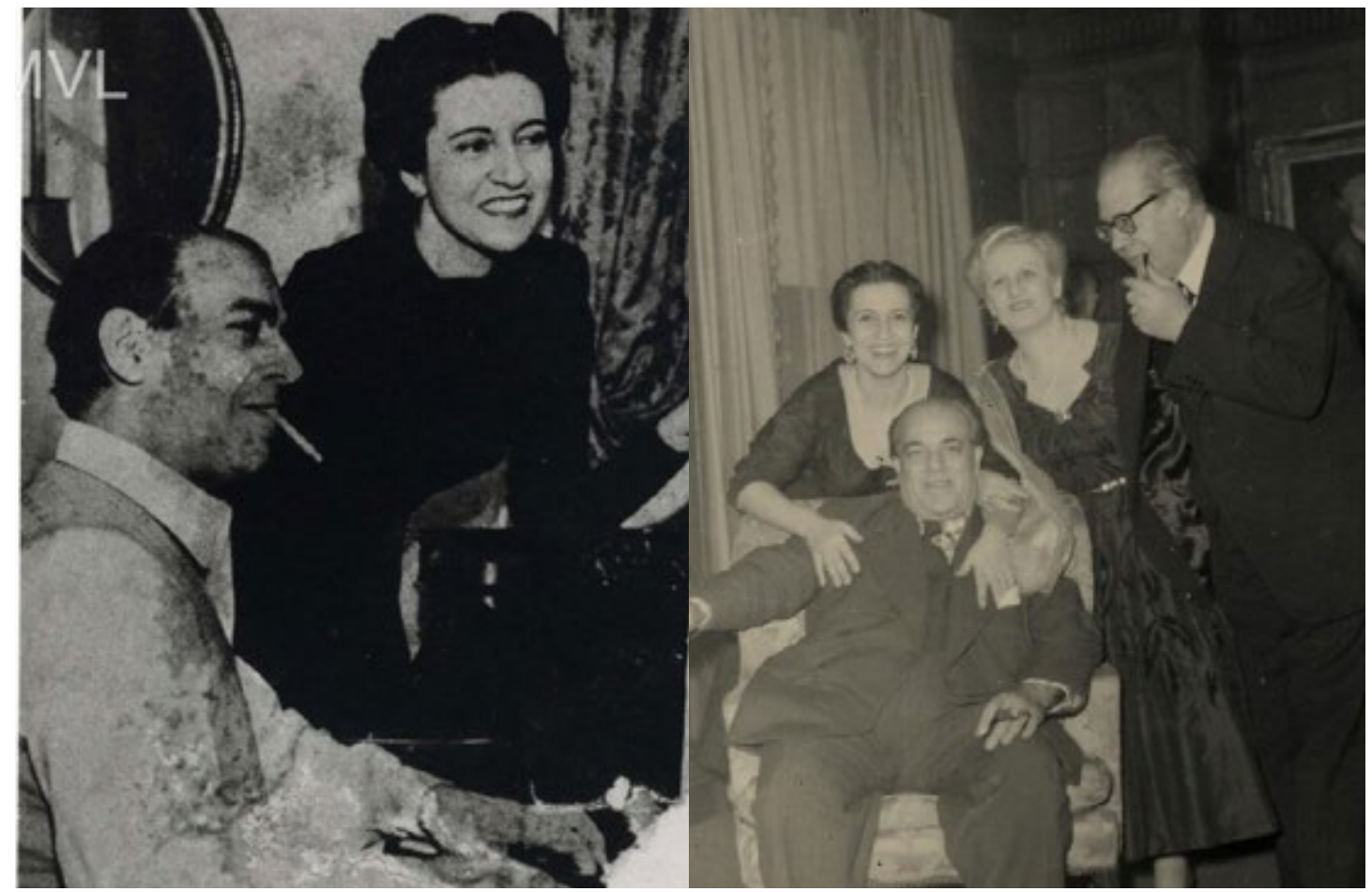

Fig. 8 (à esquerda): Villa-Lobos ao piano e a soprano Olga Praguer Coelho, registro de 1953. Fonte: Museu Villa-Lobos, Fotografias, N. de registro 1987.16.062.

Fig. 9 (à direita): Villa-Lobos (sentado), Olga Praguer Coelho, Arminda Villa-Lobos e Andrés Segovia, registro de março de 1958. Fonte: Museu Villa-Lobos, Fotografias, N. de registro 1977.16.256.

A "Canção do Poeta do Século XVIII" foi, portanto, a terceira adaptação do próprio Villa-Lobos de obras suas de outras formações para duo de canto e violão. A par do que ocorrera com a versão original, a peça aguardou quase uma década para ser programada. Apenas em 12 de novembro de 1962, Cristina Maristany e Jodacil Damaceno (1929-2010) realizaram a estreia, no Auditório do Palácio da Cultura (RJ) - MEC, durante a programação do Festival Villa-Lobos daquele ano. Maristany, como vimos, já havia estreado a versão para canto e orquestra dois dias antes, sob a regência de Eleazar de Carvalho no Theatro Municipal do Rio de Janeiro.

A pesquisadora, violonista e professora Sandra Mara Alfonso (UFU), biógrafa de Jodacil Damaceno, pontua que a edição de julho/agosto de 1963 da revista inglesa Guitar News, "um dos mais importantes meios internacionais de divulgação do violão na época publicou uma matéria enviada por Jodacil sobre a Semana Villa-Lobos, divulgando o evento, a obra de Villa-Lobos e o movimento do violão no Brasil" (ALFONSO, 2017, p. 86).

Na revista inglesa, são reproduzidas três fotos do Festival de 1962, histórico para o instrumento, já que nele ocorreram as estreias de "Canção do Poeta do Século XVIII" (com Jodacil Damaceno e Cristina Maristany), do "Sexteto Místico" (com Turíbio Santos e músicos da Orquestra Sinfônica Nacional) e da integral dos "12 Estudos" para violão (com Turíbio Santos). 


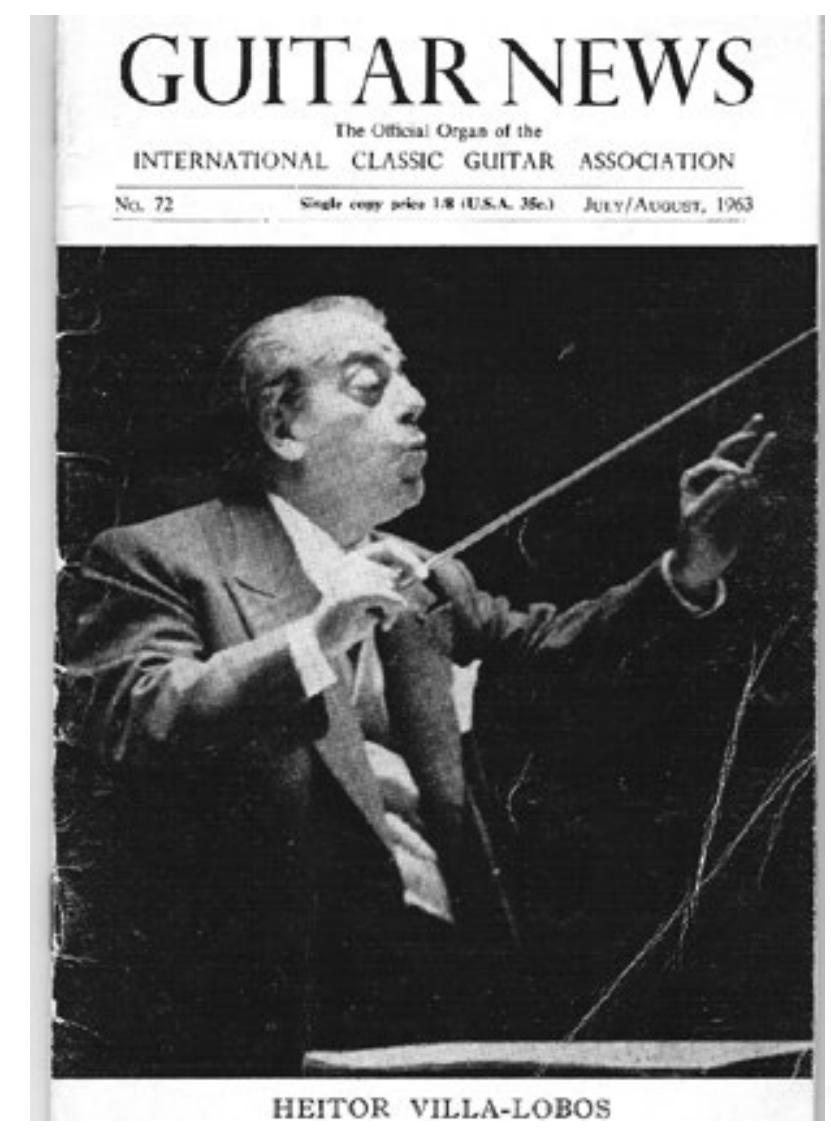

DariAut, 1963

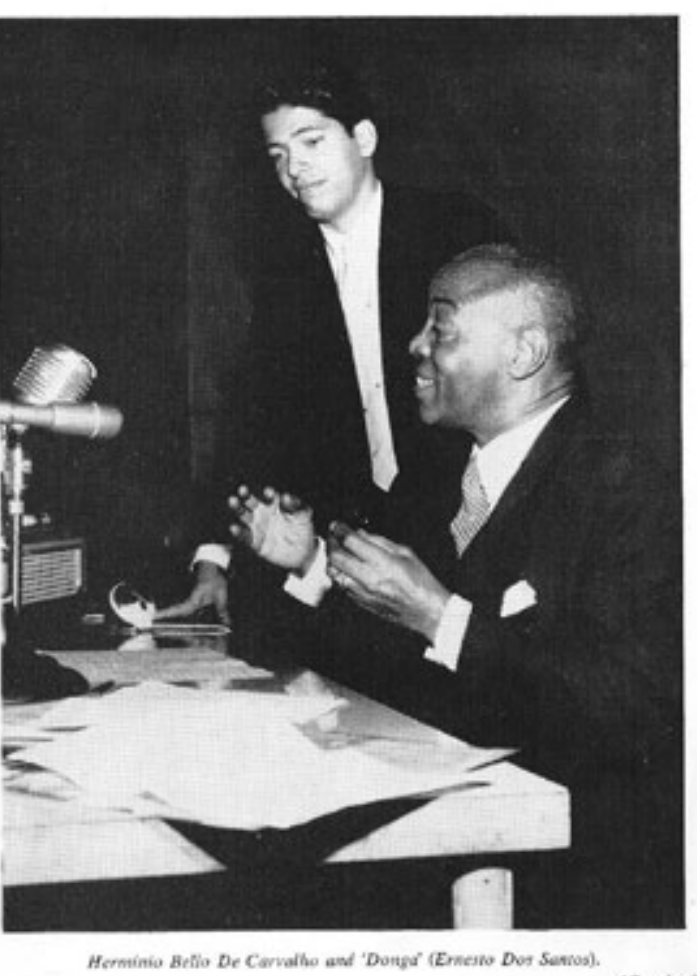

Fig. 8 e 9: À esquerda, revista Guitar News com Villa-Lobos em destaque na capa; à direita, Hermínio Bello de Carvalho (em pé) e Ernesto dos Santos ("Donga"), personagens que conviveram com Villa-Lobos e estiveram presentes na estreia de "Canção do Poeta do Século XVIII". Fonte: Guitar News, n. 72, p. 5, jul./ago, 1963.

$\mathrm{Na}$ matéria, a revista oferece detalhes sobre as atividades que compuseram o evento: "concertos públicos, programas de rádio e televisão e uma palestra protagonizada pelo jovem poeta Hermínio Bello de Carvalho", destacando ainda o papel do Museu Villa-Lobos e de "Mindinha Villa-Lobos" na organização do Festival (GUITAR NEWS, 1963, p. 3-4).

Durante a palestra, Herminio Bello de Carvalho pôs para tocar uma gravação de "Introdução aos Choros", escrita em 1929 para violão e orquestra: solista José Menezes. O compositor Donga (Ernesto dos Santos), antigo amigo de Villa-Lobos e um chorão como o grande mestre, narrou alguns incidentes das aventuras de ambos na juventude ${ }^{11}$ (GUITAR NEWS, 1963, p. 4, tradução nossa).

Nas entrelinhas, pode-se perceber como a descrição das atividades do evento demonstra o caráter transitivo da produção para violão de Villa-Lobos: primeiro, Hermínio ilustrou a sua conferência com a audição de uma das peças clássicas mais icônicas do compositor, a "Introdução aos Choros", tendo como solista o cearense Zé Menezes (1921-2014), um personagem que fez carreira como violonista/guitarrista, compositor e arranjador no rádio, na televisão e na indústria fonográfica mais vinculada à "música

11 Original: "During the lecture, Herminio Bello de Carvalho played a recording of 'Introdução and Chôros" (introduction to the Chôros, written in 1929) for guitar and orchestra: soloist Jose Menezes. The composer Donga (Ernesto Dos Santos) and old-time companion of Villa-Lobos and a 'chorão' like the great master, narrated a few incidentes of their adventures as young men". 
popular", tocando ainda em regionais e grupos camerísticos famosos; depois, note-se que a revista destaca a participação de outro personagem crossover, Ernesto dos Santos (1889-1974), o "Donga", que pontuou na ocasião as aventuras vividas ao lado de Villa-Lobos nos tempos de "chorão" boêmio. Donga estudou com Quincas Laranjeiras (1873-1935), frequentou a casa de Tia Ciata, integrou com Pixinguinha o célebre grupo dos Oito Batutas, além de ter sido o autor de "Pelo Telefone", estimado como o primeiro samba registrado fonograficamente (1916).

A revista ainda sugere que o palestrante Hermínio Bello de Carvalho pretendia "publicar um livro para contar a relação de Villa-Lobos e os chorões" e no qual o violão teria um capítulo em destaque, dada a sua importância na produção geral do compositor. A publicação, no entanto, aguardou mais de duas décadas para ser efetivada, em O Canto do Pajé: Villa-Lobos e a Música Popular Brasileira (1988). Nela, Carvalho ratifica a decisiva influência dos "chorões" na formação musical transitiva do compositor:

\begin{abstract}
Não se pode dizer que Villa tenha sido um músico de formação popular, pelo contrário. Seu primeiro contato foi com aquela música rígida, que era praticada largamente em serões de sua casa. Da música popular, ele recebeu uma informação posterior: era um apelo instintivo que lhe chegava da rua, através dos chorões e seresteiros que praticavam uma música de irresistível flexibilidade, cheia de sugestões originais. Ele foi, depois, compartilhar e conviver com esses músicos, fazer parte das rodas de choro, levar escondido seu violão para encostar sua sensibilidade naquela gente humilde, que fazia uma música que o apaixonava terrivelmente (CARVALHO, 1988, p. 52).
\end{abstract}

Note-se, uma vez mais, como as dualidades se atravessam na descrição formativa de Villa-Lobos levada a cabo por Hermínio Bello de Carvalho, personagem que com ele conviveu e foi um dos primeiros estudiosos de sua produção para violão. O desdobramento da proposição antropofágica de Oswald de Andrade parece ganhar contornos mais nítidos a partir da leitura ensaística de Carvalho: nem só clássico e nem só popular, mas isto e aquilo: "o som brasileiro que encontramos com características da obra de Villa é o som das modas de viola, dos sambas de rua, dos catimbós, das catiras, dos choros tirados dos violões e flautas [...]" (CARVALHO, 1988, p. 53).

É preciso destacar ainda que, de maneira prática e simbólica, este aspecto transitivo da produção para violão de Villa-Lobos não se limitou ao seu período formativo, mas encontrou ressonância durante toda a trajetória do compositor, esgueirando-se e tornando-se visível também na diversidade dos personagens que o compositor atraía e com os quais convivia. A foto panorâmica tirada na ocasião da estreia de "Canção do Poeta do Século XVIII", no auditório do Palácio da Cultura durante o Festival Villa-Lobos de 1962, é a constatação viva de que o violonismo villalobiano era (e é) um polo atrativo capaz de integrar múltiplas camadas do violão no Brasil (e para além dele, se tomarmos como perspectiva um cenário musical mais amplo): de Monina Távora a Donga; de Turíbio Santos a Ismael Silva; de Jodacil Damaceno a Jacob do Bandolim; de Mozart de Araújo e Hermínio Bello de Carvalho, estudiosos do violão, a Cristina Maristany e Mario Cabral, personagens importantes de outros instrumentos. Isto e aquilo: Tupi and not Tupi. 


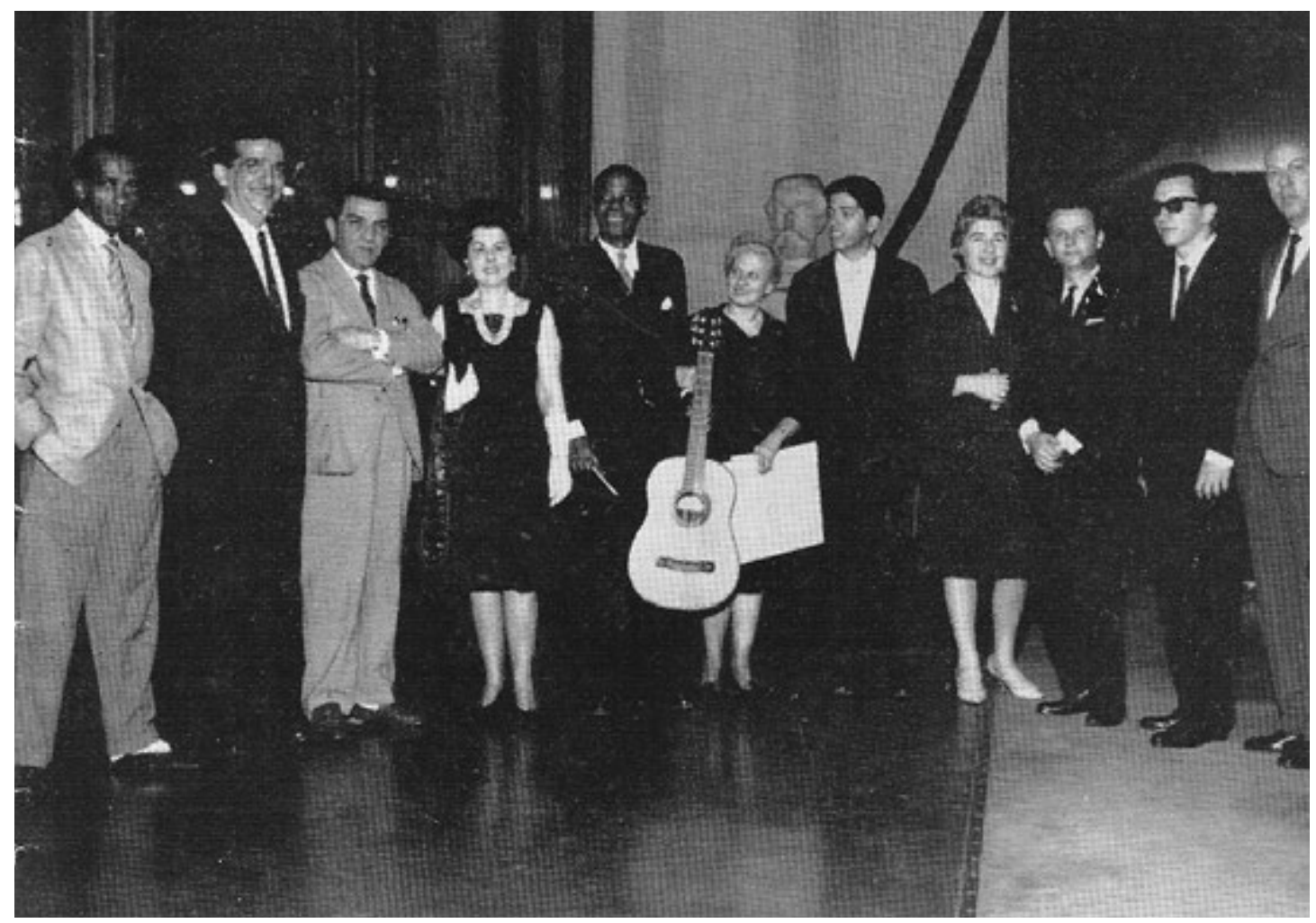

Fig. 11: Auditório do Palácio da Cultura, 1962: Ismael Silva, Jacob do Bandolim, Mozart de Araújo, Cristina Maristany, Donga, Arminda das Neves, Hermínio Bello de Carvalho, Monina Távora, Jodacil Damaceno, Turíbio Santos, Mario Cabral (Tribuna da Imprensa) ${ }^{12}$. Fonte: Guitar News, 1963, n. 72, p. 3, jul./ago. 1963 ${ }^{13}$.

Especificamente em relação ao repertório para canto e violão, a estreia de "Canção do Poeta do Século XVIII" põe em pauta dois reconhecidos e decisivos intérpretes na promoção da obra vocal e violonística de Villa-Lobos: Cristina Maristany e Jodacil Damaceno. Sobre a cantora, sua dedicatária em algumas peças, o compositor declarava: "O seu cantar penetra no ambiente de cada canção com rara autenticidade. Intérprete fiel de todos os autores, reunindo ao apuro técnico uma espontânea e surpreendente musicalidade" (apud AMARAL, 2010, p. 289). Por sua vez, ao lado de Turíbio Santos, Damaceno foi o grande responsável pela afirmação da obra violonística de Villa-Lobos no Brasil a partir da década de 1960 (antes disso, a produção violonística villalobiana só tinha sido visitada espaçadamente).

\footnotetext{
12 A presença destes personagens é ratificada no livro de Hermínio Bello de Carvalho: "[...] A própria Mindinha, por diversas vezes, me levou para fazer palestras sobre o Mestre. A primeira delas foi em 63 [1962], no hoje Palácio Gustavo Capanema. Palestra que até mereceu críticas dos professores Andrade Muricy, Eurico Nogueira França, Ayres de Andrade, e, se não me engano, de Dona Ondina Ribeiro Dantas (a d'Or) [...]. Lembro que exaltaram a exemplaridade da conferência: o depoimento ao vivo de Donga, primeiras audições a cargo dos ilustradores (Jodacil Damaceno, Turíbio Santos e soprano Cristina Maristany) e, na plateia, figuras iguais a Jacob do Bandolim, o crítico e pianeiro Mário Cabral, Monina Távora, Mozart de Araújo, Ismael Silva e não recordo mais quem (CARVALHO, 1988, p. 27).
}

13 Uma cópia da Revista Guitar News nos foi gentilmente cedida pela violonista, professora e pesquisadora Sandra Mara Alfonso, a quem agradecemos a generosidade. 


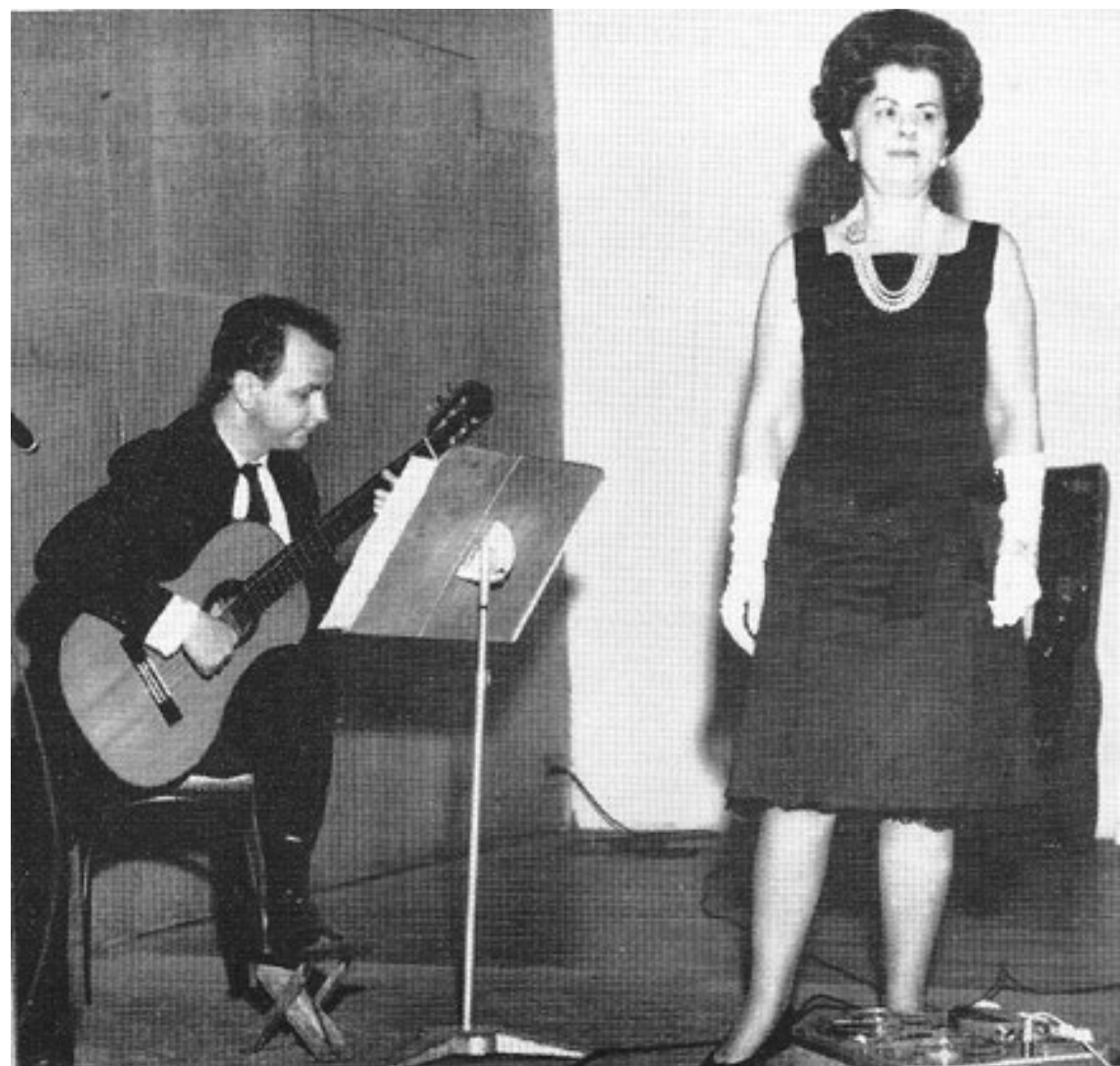

Fig. 10: Jodacil Damaceno e Cristina Maristany na ocasião da estreia de "Canção do Poeta do Século XVIII". Auditório do Palácio da Cultura (RJ) - MEC, 1962. Fonte: Guitar News, n. 72, p. 4, jul./ago. 1963.

Depois de analisar os arquivos pessoais do violonista em dois momentos diversos ${ }^{14}$, foi possivel reunir dezenas de programas de concertos, entre as décadas de 1960 e 1970 , nos quais Villa-Lobos recorrentemente constava, geralmente ocupando toda a programação ${ }^{15}$. Além disso, após a morte do compositor, Damaceno foi um dos personagens do violão mais próximos da viúva Arminda Neves de Almeida, que recorrentemente o chamava para participar das programações e promoções do Museu Villa-Lobos.

Esta relação estreita entre Damaceno e a obra de Villa-Lobos fica expressa já nas reportagens que cobriram a estreia. A apresentação, aliás, não contou apenas com números musicais: além de Turíbio Santos tocar os "12 Estudos" e de Jodacil Damaceno e Cristina Maristany interpretarem as três peças vocais até então transcritas pelo compositor para voz e violão ("Ária da Bachianas Brasileiras no 5", "Modinha" e "Canção do Poeta do Século XVIII"), Hermínio Bello de Carvalho realizou a palestra "Villa-Lobos, uma

14 Primeiramente em 2007, quando realizei entrevistas com o intérprete ainda vivo e tive acesso ao material em sua antiga residência no bairro da Tijuca, no Rio de Janeiro. Depois, em março de 2019, quando cataloguei o acervo do saudoso violonista, falecido em 2010, já então abrigado pela biblioteca da Universidade Federal de Uberlândia (UFU), em Minas Gerais.

15 Damaceno foi ainda um dos três violonistas, ao lado de Turíbio Santos (1943, 76 anos) e Hermínio Bello de Carvalho (1935, 84 anos), que estiveram presentes na famosa "Conferência de 1957" que Villa-Lobos realizou, no Conservatório Nacional de Canto Orfeônico (com sede no atual Instituto Benjamim Constant), sobre sua produção para violão. A presença de Damaceno nos foi corroborada pelo próprio intérprete em entrevistas particulares realizadas em fevereiro de 2007, nas quais o violonista forneceu diversas informações que teriam sido ditas pelo próprio compositor, na ocasião, e cujo conteúdo se encontra parcialmente exposto em nossas publicações anteriores sobre o tema (AM0RIM: 2007; 2009). 
conferência", publicada no ano seguinte pelo Museu Villa-Lobos (1963) ${ }^{16}$.

A programação foi, por isso, denominada pelo Jornal do Commercio de "recital-conferência", em sua edição de 11 de novembro de 1962, véspera do evento. Além de divulgar o programa, a data e o horário (17 horas), a matéria ainda publicou a hoje famosa fotografia do compositor com o violão no colo, mas que, naquele momento, era recente e desconhecida a tal ponto que foi anunciada como inédita no Brasil. Segundo o jornal, o registro pertencia ao acervo particular de Damaceno, em mais um indício da estreita relação do intérprete com a obra violonística do compositor.

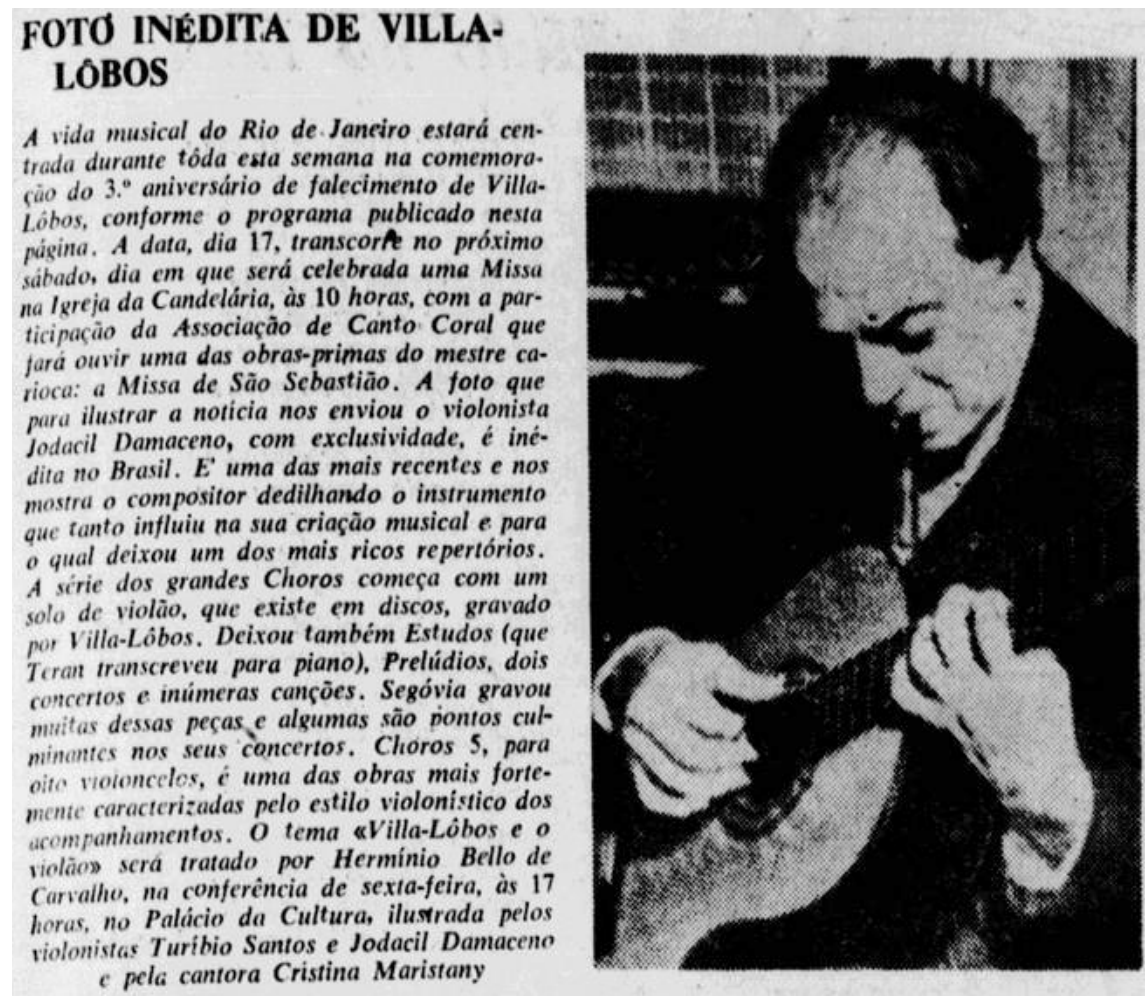

Fig. 9: Chamada para o recital-conferência realizado no Palácio da Cultura, dentro da programação do Festival Villa-Lobos de 1962, com a estreia da versão para canto e violão de "Canção do Poeta do Século XVIII". Fonte: Jornal do Commercio (1962).

A partir das estreias das obras na década de 1960, Jodacil Damaceno seguiu sendo o violonista que mais difundiu a produção para canto e violão de Villa-Lobos em terras brasileiras. A "Canção do Poeta do Século XVIII", por exemplo, foi programada pelo intérprete dezenas de vezes entre as décadas de 1960 e 1980, sempre ladeado por

\footnotetext{
16 Hermínio Bello de Carvalho também realizou esta conferência em Lisboa, em 26 de outubro de 1963, conforme consta na edição do jornal Tribuna da Imprensa de 18 de outubro daquele ano. A palestra teve, inclusive, a participação do famoso violonista português José Duarte da Costa (1921-2004): "Muita gente (críticos, sambistas, Elizete, Clementina de Jesus) no Galeão, na tarde de sábado, indo se despedir de Hermínio Bello de Carvalho, que seguiu para a Europa, comissionado pela Difusão Cultural do Itamarati para fazer palestras sobre música brasileira e especialmente sobre Villa-Lobos. No roteiro de Hermínio, a primeira palestra: dia 26, em Lisboa, ilustrada pelo violonista Duarte da Costa, com uma soprano portuguesa interpretando a "Bachiana n ${ }^{\circ} 5$ " e, em fita, a "Canção de um Poeta do Século XVIII"' e a Introdução aos "Choros" (TRIBUNA DA IMPRENSA, 1963). Desconhece-se qual seria a mencionada gravação em fita da "Canção do Poeta do Século XVIII" (ou ainda se era um registro comercial ou caseiro), mas, se de fato existiu, ela seria anterior à realizada por Ludna Biesek e Jodacil Damaceno.
} 
cantoras de significativa expressão: Maria Riva-Mar ${ }^{17}$, Fátima Alegria ${ }^{18}$ e Eliane Sampaio.

Os recitais em duo com esta última, aliás, ganharam relevo nos jornais em princípios da década de 1970. No Jornal do Brasil (1972), a coluna de Edino Krieger (1928, 91 anos) enfatizou o programa tocado no Parque da Cidade, no Rio de Janeiro, em 17 de setembro de 1972. Já o Diário de Notícias dedicou uma chamada com foto para o programa realizado pelos artistas quase um mês antes, em 24 de agosto de 1972, no Auditório do DER (RJ). A matéria recebeu o título de "Modinhas inéditas, hoje", destacando como o repertório "foi elaborado de forma a mostrar o desenvolvimento da Modinha Brasileira desde o século XVIII até os nossos dias" (DIÁRIO DE NOTÍCIAS, 1972). Em adaptações para violão, modinhas de Marcos Portugal e Joaquim Manuel da Câmara preenchiam a primeira parte do programa. Na segunda, Damaceno ganhava destaque solando e acompanhando peças de Villa-Lobos e Jayme Ovalle (1894-1955):

A segunda parte do concerto é aberta com 5 Prelúdios de Villa-Lobos, por Jodacil Damaceno, seguindo-se uma seleção de canções com conotação de Modinha, a saber: Azulão e Modinha de Jayme Ovalle; Canção do Poeta do Século XVIII, Modinha (Seresta no 5), Lundu da Marquesa de Santos e Canção do Amor, de Villa-Lobos.

Os mesmos intérpretes apresentarão este programa em Belo Horizonte e Vitória (Espírito Santo), apresentações incluídas nas comemorações locais do Sesquicentenário (DIÁRIO DE NOTÍ́CIAS, 1972).

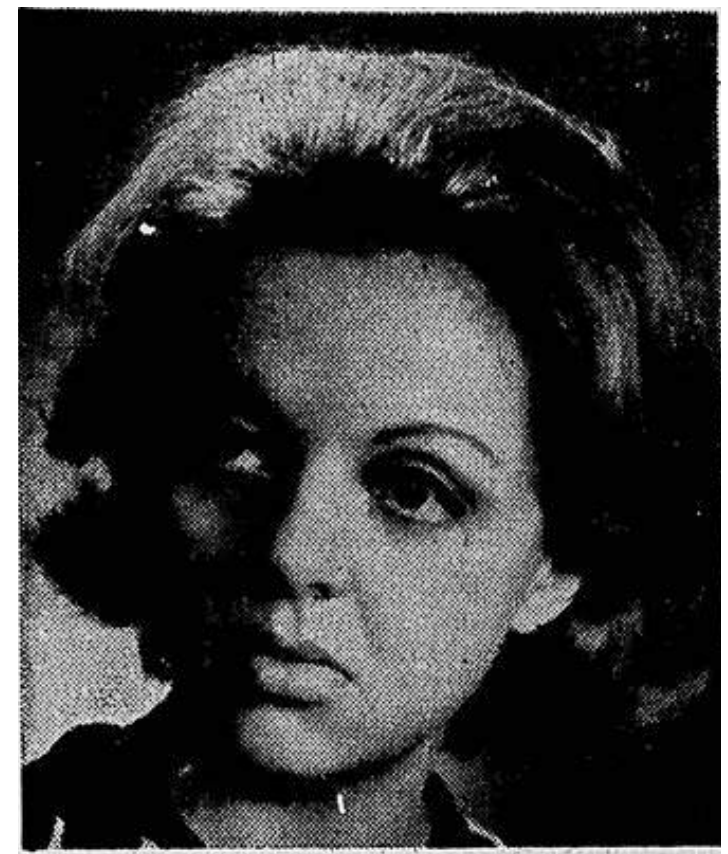

Fig. 10: Foto de Eliane Sampaio no Diário de Notícias de 24 de agosto de 1972, em chamada do concerto em duo com Jodacil Damaceno realizado no Auditório do DER, no Rio de Janeiro. Os artistas interpretaram, dentre outras peças, a "Canção do Poeta do Século XVIII", de Villa-Lobos. Fonte: Diário de Notícias (1972).

\footnotetext{
17 Incluindo uma apresentação na Sala Cecília Meireles, no Rio de Janeiro, dentro da programação do Festival Villa-Lobos de 1974 (JORNAL DO BRASIL, 1974a, 1974b).

18 Um dos recitais do duo chegou a ganhar destaque na coluna de Luiz Paulo Horta, no Jornal do Brasil: "[...] Hoje, às 21 horas, no auditório da Sondotécnica (Largo dos Leões), a soprano Fátima Alegria e o violonista Jodacil Damaceno interpretam um programa Villa-Lobos que inclui peças para violão solo, serestas, canções e a Cantilena da Bachiana Brasileira n $5^{\prime \prime}$ (JORNAL DO BRASIL, 1979).
} 
Eliane Sampaio, aliás, também fez duo esporádico com outro personagem decisivo para a afirmação do repertório violonístico de Villa-Lobos no Brasil e no mundo: Turíbio Santos. Ambos chegaram a apresentar peças do compositor (dentre outros autores brasileiros) na Sala Cecília Meireles, no dia 1ํ de setembro de 1973. À época, o violonista morava em Paris e passava três meses no Brasil, de junho a início de setembro, quando desenvolvia trabalhos musicais dos mais diversos, sobretudo tocando e ensinando. Nesta ocasião, por exemplo, acabara de participar do Festival de Campos do Jordão. O Jornal do Brasil deu amplo destaque ao concerto do duo, especialmente a Turíbio, intitulando o programa de "Melodias brasileiras num violão internacional".

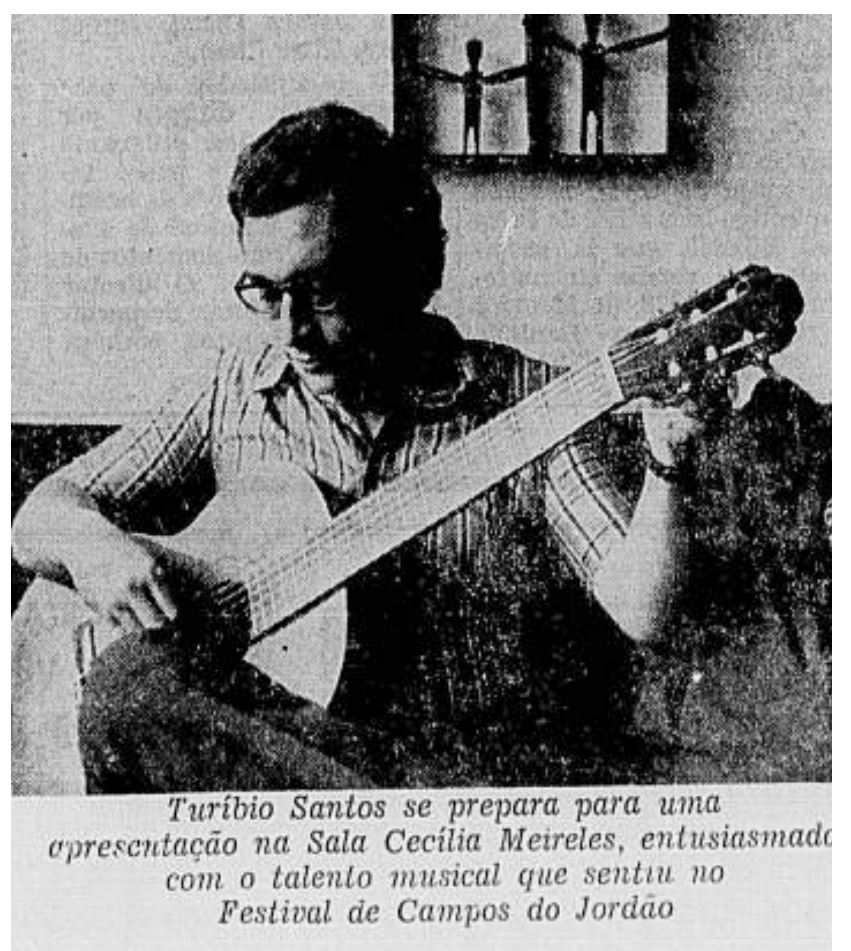

Fig. 11: Foto da chamada do concerto de Turíbio Santos e Eliane Sampaio na Sala Cecilia Meireles. Na matéria, uma curiosa descrição: "Mais gordo, com a mulher e os dois filhinhos, Turíbio não está gozando férias. Veio trabalhar e passou todo o mês de agosto preparando seu próximo concerto" (JORNAL DO BRASIL, 1973b).

\section{A primeira gravação (1967): Jodacil Damaceno (violão) e Ludna Biesek (canto)}

A convite de Mindinha, Damaceno também foi o responsável pela primeira gravação da versão para canto e violão, em álbum publicado pela série Classic, da Riosom RSCL 4006, uma promoção do Museu Villa-Lobos (MVL) em parceria com o Ministério da Educação e Cultura (MEC) para o Festival Villa-Lobos de 1967. Intitulado Villa-Lobos: Prelúdios e Canções, o disco apresentava a integral dos "Cinco Prelúdios" para violão solo no lado A, além de quatro canções divididas pelo violonista com a voz de Ludna Biesek no lado B: "Canção de Amor", "Modinha", "Ária da Bachianas Brasileiras nํ5" e "Canção do Poeta do Século XVIII". 


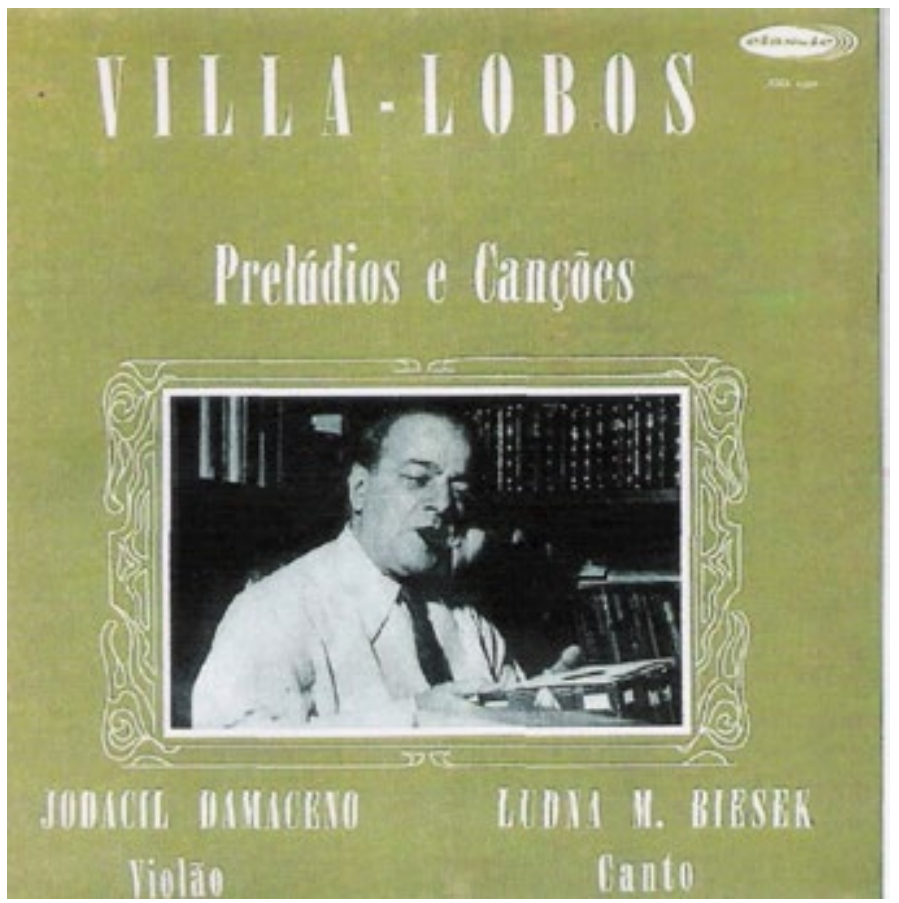

Fig. 12: Capa do disco Villa-Lobos: Prelúdios e Canções, protagonizado por Jodacil Damaceno (violão) e Ludna M. Biesek (canto). Fonte: Acervo pessoal de Jodacil Damaceno cedido ao autor em 2007.

Assim que lançado, pulularam críticas ao disco nos jornais cariocas mais importantes: em linhas gerais, favoráveis ao trabalho do violonista e devastadoras em relação à atuação da cantora. Na coluna "Música", do Jornal do Brasil, Renzo Massarani pontuou que Damaceno deu "um excelente relevo aos Prelúdios" e atuou "muito bem acompanhando Canção de Amor, Canção do Poeta do Século 18 e particularmente a inigualável Modinha", ponderando que, ao contrário, o seu violão não pareceu "poder substituir os violoncelos originais da Cantilena". Sobre Ludna, o tom foi diferente, com o crítico sugerindo que, tanto "na gravação em apreço, como no recente concerto da Semana Villa-Lobos, [a cantora] não soube dar à obra-prima ["Ária das Bachianas Brasileiras no 5"] suficiente emoção nem firmeza de voz (JORNAL DO BRASIL, 1967, grifos no original).

O jornal O Dia (1967) frisou que, com o disco, Damaceno prestava "um grande serviço à música brasileira, tornando ainda mais popular o violão". Em O Globo, Zito Batista Filho seguiu o mesmo script, elogiando o violonista e fazendo ponderações à performance de Biesek: "Este disco é mais uma realização positiva do talento de Jodacil Damaceno, que alia técnica, sonoridade e estilo num mesmo nível alto para produzir um Villa-Lobos autêntico, vivo, popular e universal". Já em relação à soprano, pontuou que a intérprete foi "menos feliz porque trai alguma preocupação que lhe prejudica a espontaneidade, no entanto, é agradável o seu timbre, simpática a sua voz" (apud ALFONSO, 2017, p. 103).

Entretanto, a tinta mais carregada (para o bem e mal) foi a de João Tererê. Em sua coluna de nome sugestivo, "Agulha-no-Prato", publicada no jornal O Dia, o crítico exaltou Damaceno e não poupou as escolhas técnicas e estéticas de Biesek na interpretação das quatro obras vocais. 
[...] esta edição tem na face A sua melhor feição. Os cinco prelúdios do nosso maior gênio musical atestam aquela simbiose perfeita do autor com seu instrumento preferido - o violão. E encontram, em JODACIL DAMACENO, o intérprete, a ressonância fiel. Pois que, acima de tudo, o calado, o modesto JODACIL é um ser fiel. A técnica honesta, conquistada dia-a-dia, a sonoridade delicada, o claro acabamento de cada frase, tudo atesta essa fidelidade do violonista, não servilismo, não falta de imaginação, mas dedicação aos mestres, apego à sua atividade de retratar o gênio. Há também um quê de meigo na forma tranquila e segura com que Jodacil transmite, através das faixas, a criação do mais impetuoso de nossos artistas.

Já o mesmo não poderemos dizer do soprano LUDNA BIESEK. Nós nos opomos terminantemente a essa maneira de cantar concertisticamente, com prosódia estrangeirada, as canções de inspiração popular. Toda a singeleza e a autenticidade da criação melódica são jogadas ao chão pelo preciosismo da pronúncia, aqueles "rr" borbulhantes, as vogais ovaladas como fala de mulher-macho, os "uu" pontudos e guturais, como os da língua francesa ou alemã. Duvido que alguém consiga entender uma só palavra da segunda parte da Cantilena das Bachianas n. 5. Estamos fazendo aqui uma consideração geral, ignorando por completo se a cantora Biesek tem sotaque porque é estrangeira ou não.

Nossa observação parte do fato de que qualquer uma de nossas intérpretes vocais, mesmo as de formação inteiramente nacionalista, mesmo aquelas que jamais puseram o pé fora do país e excursionaram somente até Niterói, adotam, não se sabe porque, essa forma de prosódia odiosa, descabida, inteiramente divorciada da atmosfera das canções ligadas à alma popular. Assim, nossa restrição à face $B$ do LP é radical quanto à parte cantada. A atuação de Jodacil Damaceno na baixaria da Cantilena também é menos feliz que seus solos da face A por certa deficiência que nos parece ser da redução para violão. De qualquer forma, os Prelúdios e Canções de Villa-Lobos nesta edição da Classic merecem fazer parte da discoteca daqueles que apreciam o autor e um bom violão. É um disco tecnicamente limpo e Jodacil Damaceno, um intérprete de classe (apud ALFONSO: 2017, p. 103-104, grifos nossos).

Em 2007, durante as entrevistas que realizamos com Jodacil Damaceno, o questionamos sobre as críticas conferidas ao trabalho da soprano com a qual dividiu os registros fonográficos. Segundo o violonista, o disco quase não existiu, uma vez que a cantora passou muito mal em estúdio, interrompendo por várias vezes a sequência das gravações. Biesek estava grávida e, horas depois, viria a perder a criança que esperava.

Todavia, as avaliações negativas, especialmente as de João Tererê e Zito Batista Filho, parecem ter ido além de uma grave (e trágica) incapacidade momentânea da cantora, relacionando-se mais com a forçosa tentativa de conferir um ar demasiado "erudito" às canções, retirando delas, assim, a "espontaneidade" e a leveza típica dos gêneros que as inspiraram, além de dificultar o entendimento das letras com uma escolha prosódica mais arraigada às línguas europeias. Não parece à toa que as críticas, por isso, tenham também se estendido às suas performances ao vivo. Assim, a questão estética/ estilística em torno das obras para voz e violão de Villa-Lobos é posta em pauta: qual seria a abordagem adequada para que tais peças não se divorciassem da "atmosfera das canções ligadas à alma popular"?

A possível "identidade transitiva" das peças parece, nesse sentido, oferecer uma possibilidade de leitura mais abrangente da obra para canto e violão de Villa-Lobos. Como foi observado, os comentários estéticos promovidos pelos críticos das primeiras 
interpretações e/ou gravações de "Canção do Poeta do Século XVIII" demonstram que, apesar do conceito não existir à época, uma eventual abordagem transitiva já era instigada e requerida por parte daqueles que debatiam a música brasileira de concerto nas páginas dos jornais.

Este aspecto fica ainda mais sugestivo quando nos deparamos com a significativa quantidade de gravações das peças para canto e violão de Villa-Lobos realizadas por artistas vinculados à "música popular", conforme veremos a seguir.

\section{Desmontando as fronteiras entre o clássico e o popular}

Talvez justamente pela explícita enunciação desse caráter mais "modinheiro" e possivelmente relacionado a alguns gêneros matrizes da música brasileira, o repertório villalobiano para canto e violão tenha chegado à voz de cantoras populares expressivas já durante a década de 1960. Em 19 de novembro de 1964, por exemplo, a coluna musical de Sérgio Cabral, no Diário Carioca, nos dá conta de que Elisete Cardoso (19201970) havia subido ao palco do Theatro Municipal do Rio de Janeiro para performar a "Bachianas Brasileiras n 5". Hermínio Bello de Carvalho e Mindinha, inclusive, planejavam que ela incluísse em seu repertório outras obras vocais do compositor para o Festival Villa-Lobos do ano seguinte (1965).

[...] Porque o que interessa, o fundamental, não é comparar a interpretação de Elisete Cardoso da quinta "Bachiana", de Heitor Villa-Lobos, com a de Bidu Sayão ou de Victoria de Los Angeles. O mais importante na noite de segunda-feira passada foi que Elisete Cardoso, cantora popular, só comparável a uma Araci de Almeida, mulher excepcional, ex-cabelereira e ex-cantora de "dancing", levou milhares e milhares de pessoas para o Teatro Municipal a fim de vê-la, ouvi-la e consagrá-la com aplausos que duraram mais do que a sua própria apresentação. Estabelecer comparação de Elisete com quem estudou um, dois, vinte ou cinquenta anos é de uma burrice atroz.

A viúva Villa-Lobos e o poeta e crítico musical Hermínio Bello de Carvalho, biógrafo e amigo do imortal compositor, já asseguraram que ele, se vivo fosse, aprovaria a ideia de Elisete cantar a sua "Bachiana" número cinco. Em vida, ele convidou Sílvio Caldas e Francisco Alves para cantar obras suas.

Não importa saber se Elisete cantou uma oitava abaixo, mesmo porque não foi por causa dela, mas pelo conjunto de oito violoncelos que a acompanhou, fato que um crítico reconhecidamente fascista escondeu para invalidar o espetáculo de segunda-feira.

Enquanto isso, Elisete Cardoso se prepara para voltar ao Teatro Municipal para cantar novamente a "Bachianas" número cinco. Será dia 30. Não obstante, dona Arminda Villa-Lobos (a viúva), o maestro Diogo Pacheco e Hermínio Bello de Carvalho estão selecionando outras obras do maestro para Elisete cantar no próximo Festival Villa-Lobos, em 1965, como parte das comemorações do IV Centenário. Assim, após passar essa onda, Elisete Cardoso ensaiará a "Modinha" (letra de Manuel Bandeira), "Canção do Poeta do Século XVIII", "Canção de amor" (uma de suas últimas obras, que tem uma versão para canto e violão) e o "Samba-clássico" para voz e orquestra, que Villa-Lobos fêz em "homenagem aos músicos populares", com letra sua, sob o pseudônimo de E. [Epaminondas] Villalba Filho (DIÁRIO CARIOCA, 1964). 
Cumpre destacar que, alicerçando-se no testemunho de Arminda Neves de Almeida e Hermínio Bello de Carvalho, o crítico pontua que Villa, "vivo fosse", aprovaria a sua peça interpretada por uma cantora popular. Mais que isso, reitera que, em vida, o próprio compositor convocou dois cantores populares icônicos, Francisco Alves (1898-1952) e Sílvio Caldas (1908-1998), para interpretar suas canções. A partir de depoimentos recoIhidos diretamente de Villa-Lobos, Carvalho também comenta a possível reação que o criador teria diante de seu repertório ilustrado por vozes do cancioneiro popular:

Villa-Lobos desaprovaria a iniciativa de se fazer Elizeth cantar a "Bachianas no 5"? Vejamos: Villa-Lobos dizia que "Sílvio Caldas era o professor natural da música de câmara vocal do Brasil..." ${ }^{19}$ E tanto assim pensava que o fez apresentar-se como solista da modinha "Gondoleiro", com versos de Castro Alves, acompanhado por quase 30.000 vozes no Vasco da Gama, e com 500 músicos de banda; isso em setembro de 1941. Essa experiência de utilização de cantores populares repetiu-se com Chico Alves cantando, de Donga e David Nasser, a composição "Meu Jardim"; depois, foi Augusto Calheiros, a chamada "Patativa do Norte", cantando "Sertanejo do Brasil" (CARVALHO, 1988, p. 53-54).

Tal transitividade deixaria marcas visíveis em seu pensamento artístico, o que se observa nitidamente em boa parte de sua produção violonística ("Suíte Popular Brasileira", "Choros 1", "Prelúdio 2", "Prelúdio 5" etc.). Conforme ilustra Tomás Terán em depoimento a Carvalho:

O violão que tocava Villa-Lobos era o violão capadócio, seresteiro ${ }^{20}$. Ele era violoncelista, então usava os recursos de portamentos e tinha muita agilidade - e tudo o que tocava era diferente da escola espanhola. Mas sabia muito, todos aqueles ensinamentos (Sor, Aguado, Carulli, Carcassi) lia uma vez e já absorvia (CARVALHO, 1988, p. 161).

Também na produção que transcende o uso direto do violão, esta vivência transitiva se fez notar, uma hipótese corroborada em duas análises distintas de Mário de Andrade:

É curioso ainda notar-se sob este ponto que Villa, mais do que elementos melódicos nacionais, se aproveita de certos arabescos melódicos ou harmônicos que frequentam com assiduidade o acompanhamento dos nossos violeiros ou mesmo as suas peças solistas. Assim no choro pra flauta e clarineta, único que pude examinar, assim na Sertaneja (início e final), e muitas vezes no Trio e no

\footnotetext{
19 Carvalho ainda comenta: "Quando falei de Sílvio Caldas, esqueci-me de colocar em relevo uma observação de Villa-Lobos que parece se aplicar àquele cantor: 'o que há de mais interessante nestes choros são as cadências rítmicas (Choros nº 5) e melódicas, irregulares, postas em compasso quadrado, dando uma disfarçada impressão de rubato, ou de execução melódica se retardando, que é justamente a característica mais interessante dos seresteiros'" (1988, p. 54).

20 Nas entrevistas que realizamos, Jodacil Damaceno me confidenciou um curioso episódio. Em um dos muitos concertos de Damaceno nos quais Mindinha esteve presente, o violonista interpretou o "Choros n 1", de Villa-Lobos. Damaceno, à época, já conhecia bem a gravação da peça pelo próprio compositor, e esforçou-se por conceber uma interpretação o mais próximo possível à realizada por Villa-Lobos. Durante a audição do "Choros 1", no entanto, Mindinha, da plateia, fazia repetidos sinais para o intérprete ir com mais calma, mais devagar. Damaceno, logo após o fim da apresentação, quis saber de Mindinha o porquê daqueles sinais. Mindinha respondeu que o "Choros 1" estava muito rápido e que Villa-Lobos gostava dele mais "arrastado" e com mais "respirações" entre as frases. Damaceno retrucou dizendo que se baseara nas gravações do próprio mestre. Mindinha, então, ponderou que Villa não tinha ficado satisfeito com a própria gravação, pois acabara não se sentindo completamente à vontade no estúdio, incomodado com o fato de não poder errar, com o microfone tão perto e, sobretudo, com a formalidade do ambiente.
} 
Nonetto ${ }^{21}$

Na própria "Redondilha" [uma das Serestas] a transcrição personalíssima que Villa-Lobos empregou dos baixos cantantes de violão usados pelos nossos seresteiros provam bem o que estou falando. Ficou magnificamente bem tratado, porém um seresteiro de verdade não reconheceria naquilo o choro tradicional do violão. ${ }^{22}$

Os exemplos não param por aí: o compositor escreveu "à maneira de Sátiro Bilhar" a sua "Bachianas no 1", onde os cavaquinhos aparecem sugeridos nos cellos, logo nos primeiros compassos do primeiro movimento. O caráter "violonístico" da peça é tão evidente que o lendário violonista Sérgio Abreu (1948, 71 anos) fez uma brilhante transcrição para quarteto de violões; a versão original da "Bachianas n 5", para voz e orquestra de cellos, lembra um típico acompanhamento de choro, fato, inclusive, que pode ter instigado Olga Praguer Coelho ao pedido que resultou na transcrição da peça para voz e violão.

Podemos seguir com outras demonstrações: o "Concerto Brasileiro", para dois pianos e coro misto, foi inspirado a partir dos temas dos tangos brasileiros "Odeon" e "Atrevido", de Ernesto Nazareth; o "Choros 10" mistura sugestões de efeitos vocais indígenas ao tema primoroso do schottisch Yara, de Anacleto de Medeiros; o compositor ainda harmonizaria melodias de Catulo da Paixão Cearense, dedicando-lhe a "Valsa Tristorosa" e a "Modinha" (5ํㅡ das Serestas); e em 1950, por fim, comporia o "Samba Clássico", que traz na partitura a dedicatória "homenagem aos compositores populares do Brasil".

Em relação ao repertório para canto e violão, são numerosos os casos em que fica expressa essa capacidade do repertório villalobiano em cruzar/alargar as fronteiras, por vezes estéreis, de gêneros e/ou estilos musicais encerrados. Não cabe aqui listá-los um a um, mas tomaremos como exemplos duas gravações pontuais e pouco conhecidas, ambas realizadas na década de 1980.

A primeira é o lançamento do disco da atriz e cantora popular Teca Calazans (1940, 78 anos), realizado em dezembro de 1987, no Circo Voador, em uma noitada de serestas e modinhas que contou com a presença de Dino 7 Cordas, Oscarzinho do Violão, Claudionor Cruz e outros bambas, célebres ou anônimos.

Encabeçado pelo produtor Aluísio Falcão (criador do antigo selo Voo Livre) e no esteio das comemorações pelo centenário de nascimento do compositor, a ideia deste registro foi gravar um LP com as canções de Villa-Lobos, "mas sem a pompa do canto lírico". No jornal Tribuna da Imprensa, a reportagem anunciando o lançamento foi publicada com o sugestivo título de "Villa-Lobos na Lapa", uma alusão ao famoso bairro da boemia carioca: "[...] Tendo como cenário os Arcos e uma esperada noite de lua cheia, grandes seresteiros se apresentarão ao lado de outros anônimos que apareçam por lá com um violão" (TRIBUNA DA IMPRENSA, 1987).

21 Arquivo Mário de Andrade, Instituto de Estudos Brasileiros - USP: Fichário Analítico; texto n 7, autógrafo a tinta, ficha (11,5 x 8 cm).

22 Arquivo Mário de Andrade, Instituto de Estudos Brasileiros - USP: Fichário Analítico; texto n 12, autógrafo a tinta, ficha (11,5 x 8 cm). 
Publicada no suplemento do jornal ("Tribuna Bis"), a longa matéria trazia a ilustração de Villa-Lobos que figurava na capa do LP, além da ficha técnica do disco e de uma foto da cantora. Como o álbum não foi relançado, o belo registro é pouquíssimo conhecido.

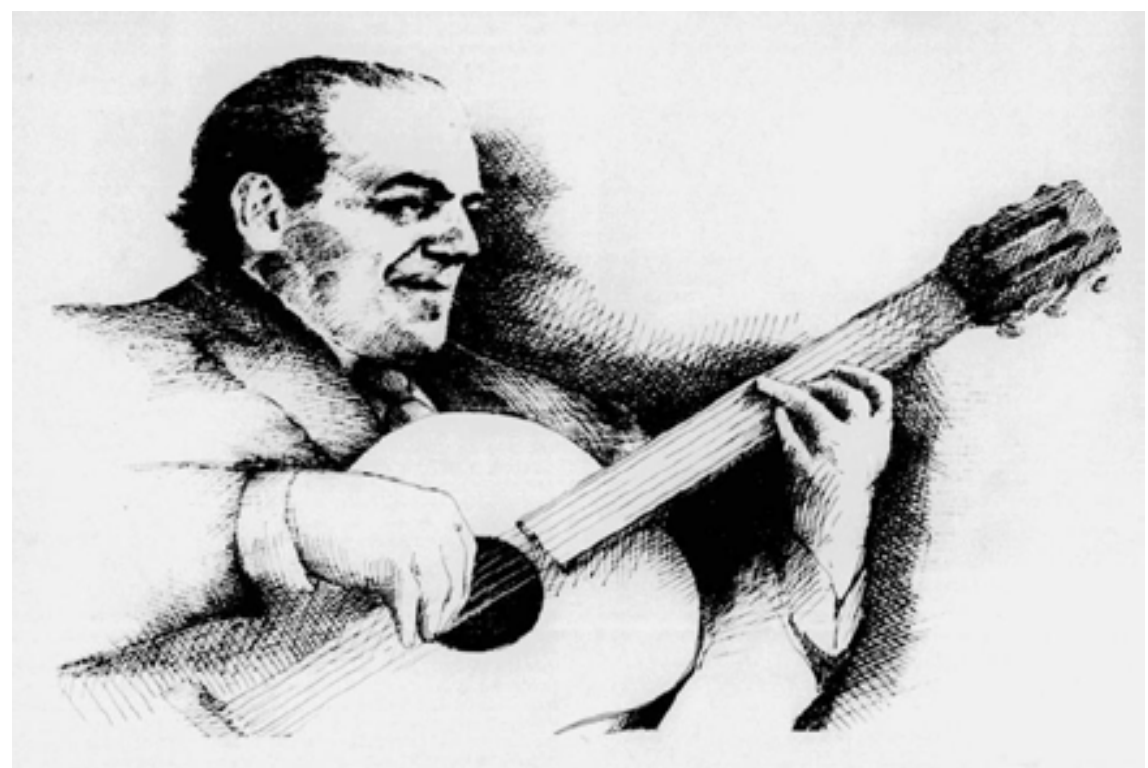

Fig. 13: Gravura de Villa-Lobos ao violão que ilustrava a capa do LP de Teca Calazans, reproduzida no suplemento do jornal Tribuna da Imprensa, em 4 de dezembro de 1987, acompanhando a chamada para o lançamento do álbum da cantora (TRIBUNA DA IMPRENSA, 1987).

Nos detalhes da ficha técnica, note-se como a "Canção do Poeta do Século XVIII" abre o lado B do disco Villa-Lobos: Serestas e Canções:
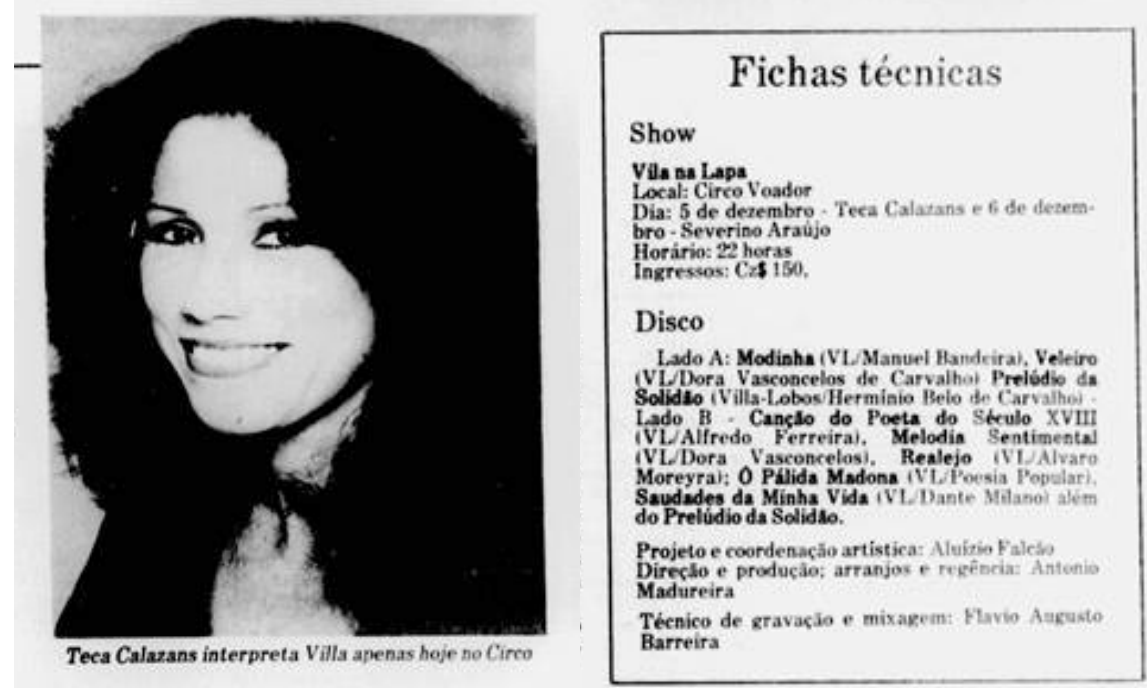

Fig. 14: Foto de Teca Calazans e ficha técnica do seu disco Villa-Lobos: Serestas e Canções (1987) Fonte: (TRIBUNA DA IMPRENSA, 1987).

O segundo exemplo revela com a mesma nitidez os traços desta transitividade da obra de Villa-Lobos entre o "clássico" e o "popular": trata-se do primeiro álbum da soprano Leila Guimarães (1957, 62 anos), desde a década de 1970 uma das cantoras líricas 
brasileiras de maior projeção internacional, vencedora de um Emmy (1982), laureada em concursos e tendo no currículo apresentações ao lado dos tenores Luciano Pavarotti (1935-2007) e Plácido Domingo (1941, 78 anos).

No LP, a soprano foi ladeada pelos violonistas João Pedro Borges, Carlos Alberto de Carvalho e o pianista João Carlos Assis Brasil. O repertório contava com a "Bachianas Brasileiras no 5", "Modinha", “Evocação", "Lundu da Marquesa de Santos", "Canção do Poeta do Século XVIII", além de quatro canções de A Floresta do Amazonas. Gravado na Sala Cecília Meireles em sistema PCM (digital) e lançado pelo selo Kuarup em 1989, o nome escolhido para o álbum é significativo: Villa-Lobos: Melodias Populares. Parece indicar que Leila também havia compreendido que o tratamento estilístico apropriado às obras não necessariamente deveria ser o mesmo que o conferido a uma ária de Puccini.

A crítica de Reynaldo Roels Jr., no Jornal do Brasil, ratifica tal perspectiva e elogia a cantora pela escolha prosódica que permitiu o entendimento das letras: "Em todas as faixas, Leila permite que se entenda cada palavra, o que não é um mérito pequeno, embora possa haver quem não goste da pronúncia dos seus erres" (JORNAL DO BRASIL, 1989).

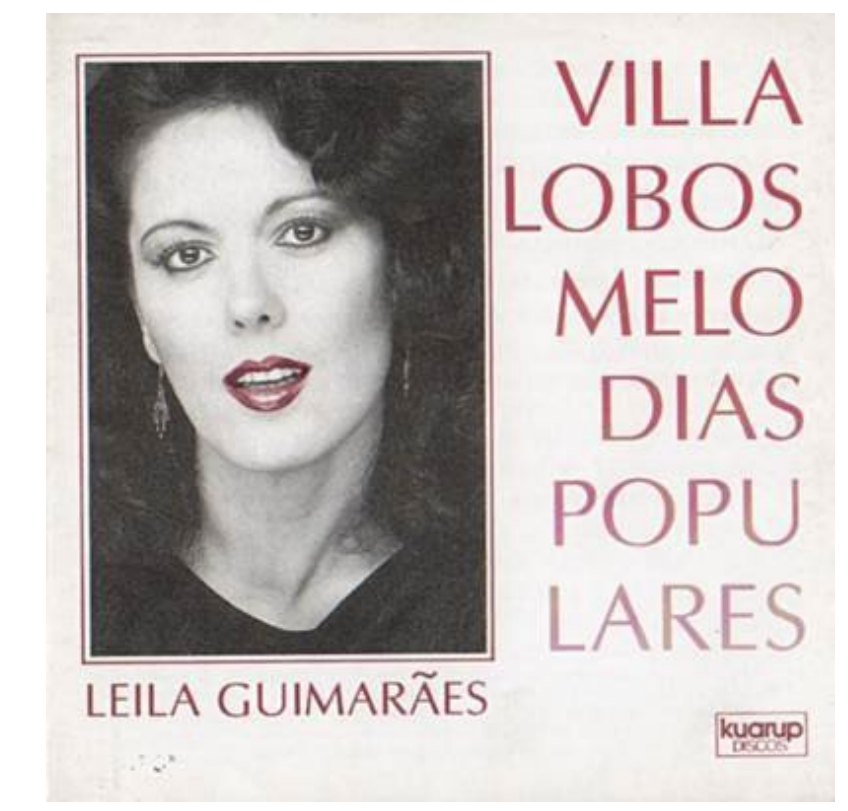

Fig. 15: Capa do LP Villa-Lobos: Melodias Populares, de Leila Guimarães. Fonte: acervo pessoal do autor.

O aspecto decisivo parece se concentrar na hipótese de que, para Villa-Lobos, as músicas advindas de tradições populares não representavam um mero exotismo ou material acessório para ser debulhado e/ou desenvolvido em suas peças clássicas, mas, sim, uma das matrizes constitutivas e indissociáveis de seu pensamento criativo e musical (por mais que o próprio compositor assim não enxergasse). Consciente ou inconscientemente, "não teve qualquer pudor ou preconceito de ir aqui e ali esgaravatar o que para alguns devia ser varrido para debaixo do tapete e que ele, de forma opulenta, cravejou na sua obra monumental" (CARVALHO, 1988, p. 148). 


\section{Outras interpretações e/ou gravações referenciais}

Pela qualidade técnica e musical, a trajetória consagrada de seus intérpretes e a repercussão que tiveram quando lançadas, outras gravações e/ou interpretações da produção para canto e violão de Villa-Lobos (particularmente da "Canção do Poeta do Século XVIII") merecem destaque. Dentre elas, figura no topo da lista o registro protagonizado pela cantora mineira Maria Lúcia Godoy (1929, 89 anos) e o violonista carioca Sergio Abreu (1948, 71 anos), ambos artistas de renomada carreira internacional.

Em 1977, no esteio das comemorações pelo 90 aniversário de nascimento do compositor, a já célebre soprano finalmente estreou em gravações comerciais com o álbum Maria Lúcia Godoy interpreta Villa-Lobos (Philips/Phonogram, n. 6598 309)23. No lado A, acompanhada por uma orquestra de violoncelos regida por Alceo Bocchino, a cantora interpretou a "Bachianas Brasileiras no 5" e outras quatro canções: "Na Paz do Outono", "Lundu da Marquesa de Santos", “Desejo" e "Cantiga do Viúvo". Já o lado B foi integralmente tomado por números villalobianos em duo com o violão de Sergio Abreu, uma parceria que começou "de brincadeira", segundo a própria Godoy revelou em entrevista concedida ao Jornal do Brasil:

A ideia de fazer o duo começou de brincadeira, lendo as quantidades de peças para voz e violão que Sergio vive comprando nas suas viagens. Líamos pelo prazer da música, até surgir o convite do Conselho Britânico para um recital na Sala Cecília Meireles. Do recital ao disco, o passo foi breve. Não foi é fácil: tanto com os violoncelos como nas faixas com o violão, a voz flutua, indefesa, e tive de adaptar-me às diferentes sonoridades, não quebrar a fragilidade das diferentes tramas (JORNAL DO BRASIL, 1977a).

As críticas ao álbum foram entusiásticas. No Jornal do Brasil, por exemplo, Ronaldo Miranda (1948, 71 anos) pontuou a longa espera pelo LP inaugural da cantora. No lado A, o crítico destacou a "emissão perfeita e a dicção irrepreensível" na "Bachianas Brasileira no 5" e a "espontânea execução" do "conhecido "Lundu da Marquesa de Santos", expresso pela solista com agógica flexível e a sua sempre excelente dicção" (JORNAL DO BRASIL, 1977). O lado B, por sua vez, foi ainda mais aclamado por Miranda:

O Lado 2 é integralmente uma obra-prima, uma verdadeira joia da discografia brasileira: à voz de Maria Lúcia se une o violão extraordinário de Sérgio Abreu, formando um duo irrepreensível do ponto de vista técnico e interpretativo.

Da atmosfera seresteira da Canção do Amor (o mais belo segmento da Floresta do Amazonas) aos vocalizes e sons onomatopaicos da Suite final (A Menina e a Canção/ Quero Ser Alegre/ Sertaneja), Maria Lúcia e Sérgio percorrem com convicção e empenho a simplicidade telúrica da Cantilena e do Remeiro de São Francisco, a linda Modinha (cujo texto de Manuel Bandeira o LP não menciona) e a expressiva Canção do Poeta do Século XVIII.

Enfim, um disco que não se deve perder, pela força do seu conteúdo estético e alto valor documental, uma vez que registra com grande categoria excelentes (e pouco divulgadas) produções vocais de Villa-Lobos. Ronaldo Miranda (JORNAL DO BRASIL, 1977b).

\footnotetext{
23 Sobre a demora para lançar o disco inaugural, Godoy ponderou: "Trata-se de um sonho acalentado ao longo dos tempos, sonho de que o próprio Heitor participou. Em geral, as companhias gravadoras não se interessam por discos ditos culturais, sob o argumento de que não têm mercado imediato. Sinceramente, não consigo entender muito esta ausência de mercado, quando vejo a Sala Cecília Meireles cheia, o Teatro Municipal de São Paulo lotado, idem, idem em Minas ou Rio Grande do Sul. De qualquer forma, graças ao empenho do diretor da Rádio MEC, Heitor Herberto Salles, e da boa vontade da Phonogram, conseguimos reunir num lado do disco a melhor orquestra de violoncelos deste país, sob a regência do maestro Alceo Bocchino, e, no outro, o maravilhoso violão de Sérgio Abreu. O parto foi longo, mas vale" (JORNAL DO BRASIL, 1977a).
} 


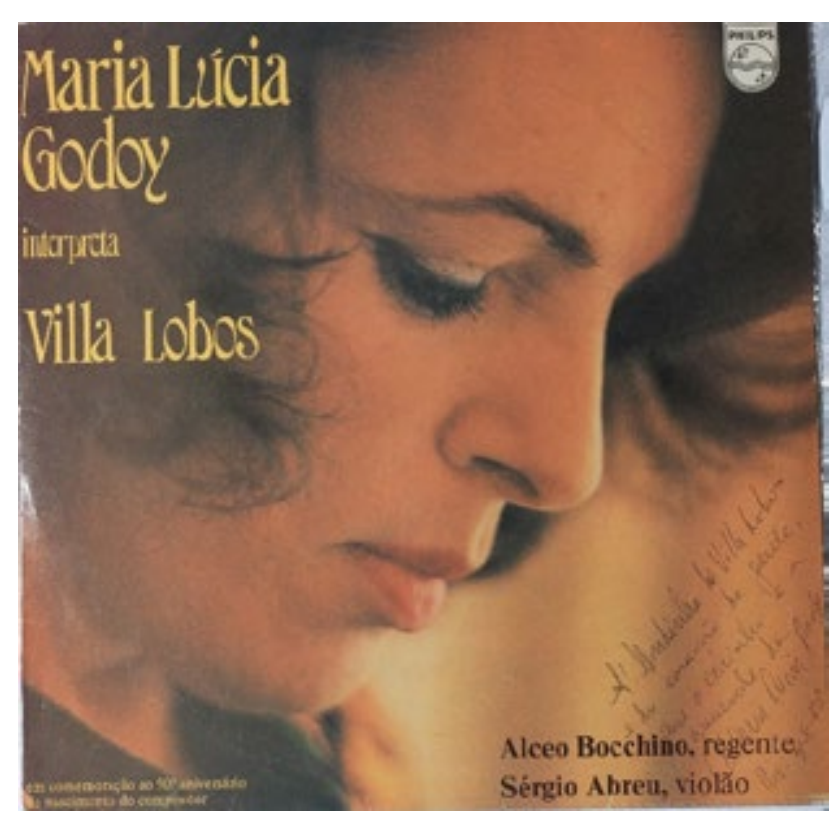

Fig. 16: Capa do LP Maria Lúcia Godoy interpreta Villa-Lobos, com dedicatória para Arminda: "À Mindinha de Villa-Lobos e do coração da gente, com o carinho e a amizade da Maria Lúcia Godoy. Rio - 4-8-83".

Fonte: Museu Villa-Lobos - Capas de disco/0890.

A gravação de Maria Lúcia Godoy e Sergio Abreu foi realizada exatamente dez anos após o registro pioneiro de Ludna Biesek e Jodacil Damaceno. Note-se como alguns dos fatores que os críticos apontaram como desfavoráveis à interpretação de Biesek (falta de espontaneidade, prosódia estrangeirada que comprometia o entendimento das letras, uma erudição exagerada que tirava a singeleza e autenticidade das melodias) são justamente os aspectos que, ainda segundo os críticos, parecem ter sido cuidadosamente debulhados por Godoy (emissão perfeita, dicção irrepreensível, execução espontânea, agógica flexível, preservando a "atmosfera seresteira" e a "simplicidade telúrica" das obras). Como vimos, a própria cantora confessou como foi difícil preservar o caráter flutuante da voz, de maneira a "não quebrar a fragilidade das diferentes tramas".

Tal fato em nada tira o mérito do precioso registro original de Ludna Biesek, uma gravação realizada sem referências fonográficas anteriores e enfrentando a ainda controversa questão estilística, naquele momento, de como as(os) cantoras(es) deveriam abordar o material de cunho nacional que atravessa as matrizes clássicas e populares. Neste sentido, é possível sugerir que o papel de Biesek foi fundamental, pois, a partir de seu álbum, os críticos e intérpretes puderam avaliar melhor as possibilidades de interpretação das peças para canto e violão de Villa-Lobos.

Assim, a celebrada gravação de Maria Lúcia Godoy e Sérgio Abreu não parece apenas consequência do brilhantismo inequívoco das capacidades musicais de ambos, mas também usufruto deste desdobramento da tradição interpretativa que, aos poucos, vai se construindo em torno de uma obra. O mesmo processo, aliás, ocorreu com as peças para violão solo do compositor (algo que abordaremos em outro estudo), que alcançaram suas gravações hoje tomadas como referenciais após décadas deste movimento coletivo de construção. Um movimento, aliás, que é sempre vivo e permanece em intermitente desconstrução/reconstrução cada vez que um intérprete cuidadoso se debruça 
sobre a música.

Em certo sentido, é a mesma perspectiva evocada pelos pesquisadores Marco Castellon e Flavio Barbeitas (2019): ao discutirem o significado estereotipado da expressão Brazilian Guitar Music, desmontam a narrativa de uma identidade nacional brasileira unificada e estanque, incapaz, segundo os autores, de alcançar a diversidade estilística do repertório brasileiro para violão:

Compreendendo identidade como algo em constante transformação e o papel do indivíduo como parte da geração de significado, concluímos que a ideia de Brasilidade também está em constante mudança. Além disso, se quisermos seguir as premissas de Mário de Andrade de 1928, apontando que "os critérios contemporâneos da Música Brasileira não devem ser filosóficos, mas sociais; deve ser um critério de combate" e que "o critério da Música Brasileira no presente deve ser o de existir em relação ao presente" [ANDRADE, 2006, p. 15], pode-se concluir: atualmente a música brasileira para violão é muito mais diversa do que as gravações podem mostrar (CASTELLON; BARBEITAS, 2019, p. 8, tradução nossa). ${ }^{24}$

\section{Considerações finais}

Dentro desta perspectiva movediça de identidade nacional, o violão tem tido um papel de destaque na mediação dos diversos signos que compõem o emaranhado tecido cultural brasileiro, transitando e absorvendo traços decisivos de todas as suas múltiplas e maleáveis camadas.

Foi e é, muitas vezes, o objeto através do qual se desmontam as divisões (quase sempre frágeis) entre tradições urbanas e rurais; clássicas e populares; pertencentes a esta ou àquela determinada classe social. Ora como ferramenta de denúncia, ora como ponto de aproximação entre polos aparentemente inconciliáveis, talvez não haja, neste sentido, instrumento musical mais democrático na história de nossa música. E aqui, pontue-se, democracia é tomada como o espaço no qual, longe de aniquilar as diferenças, é possível transformá-las em um manancial inesgotável de riquezas práticas e simbólicas. Tupi and not Tupi, em um desdobramento da proposição antropofágica de Oswald de Andrade.

A luta pela afirmação do violão na cultura brasileira espelha também a luta pela afirmação da liberdade e da diversidade como expressões inescapáveis da vida. Por isso, é sempre necessário rememorar os tempos em que andar com os dedos calejados era tomado como sinônimo de "vagabundagem"; é urgente não esquecer da severa e longa relutância vencida para que o instrumento pudesse circular (inicialmente) e ser ensinado (posteriormente) nos espaços da universidade. Atrás de nós, há o empenho e a entrega de sucessivas trajetórias para que o objeto que empunhamos sob o coração pudesse ter voz e ocupar espaços. E lutas por representatividade jamais são neutras.

24 Original: "Understanding identity as something in constant transformation and the role of the individual as part of the generation of meaning leads us to conclude that the idea of Brazilianness is also in perpetual change. Furthermore, if we are to follow the premises of Mário de Andrade in 1928, who pointed that 'the contemporary criteria for Brazilian Music must be not philosophical, but social; it must be a criteria of combat' and that 'the criteria for Brazilian Music in the present must be that it exists in relation to the present' [ANDRADE, 2006, p. 15], one might conclude: presently the Brazilian music for guitar is way more diverse than the recordings might show" (CASTELLON; BARBEITAS, 2019, p. 8). 
Recolhido por Hermínio Bello de Carvalho, o depoimento de Donga sobre os desafios de ser um violonista no Brasil em princípios do século XX parece ratificar tal perspectiva:

Todos os pais daquela época não queriam o cidadão no choro, porque era feio, era crime previsto no Código Penal [...]. O fulano (polícia) pegava o outro tocando violão, esse sujeito estava perdido, perdido! Mas per-di-do, pior que comunista. Muito pior. Isso é verdade que estou the contando, não era brincadeira não. O castigo era seríssimo. O Delegado te botava lá umas 24 horas (CARVALHO, 1988, p. 29).

Naturalmente, isto não quer dizer que houve um processo linear, como se a conquista de determinados espaços implicasse a resultante de uma lógica evolutiva no uso deste objeto sociocultural. É preciso pontuar que diversas práticas, usos e discursos permearam, concomitantemente, os caminhos do violão no Brasil.

Hoje, por exemplo, já é possível sugerir que foram decisivos tanto os que se dedicaram à consolidação do violão na tradição da música de concerto quanto os instrumentistas que se devotaram aos gêneros praticados nas ruas, uma vez que ambos os esforços são constitutivos da "identidade transitiva" que caracteriza a trajetória do instrumento em solo brasileiro. Tais práticas coexistiram (e ainda coexistem), influenciando-se reciprocamente e tornando-se a amálgama de um processo mais amplo e complexo.

Grande parte (senão a integralidade) da produção para violão de Heitor Villa-Lobos é um fruto deste processo, dele brotando na mesma proporção em que reorienta e projeta novos horizontes sob suas teias. Ao longo das décadas de 1960 e 1970, as estreias, primeiras gravações, apresentações e o debate estético/estilístico, promovido por alguns críticos em torno de suas obras camerísticas para voz e violão (enfocamos especialmente a "Canção do Poeta do Século XVIII", mas o paradigma serve às demais), levam-nos para dentro desta trama, na qual o entendimento das peças parece ter passado pela inescapável aceitação/compreensão de seus diversos e transitivos matizes (ou matrizes, se preferirmos). Parece infrutífero, portanto, dividir esta gênese em estratos estanques.

Para uma visão mais panorâmica e menos embaçada (porque o olhar, afinal, é sempre turvo), não se pode abrir mão de um dos olhos. De forma caolha e sem levar em consideração as suas diversas e emaranhadas forças constitutivas, é possível que se torne ainda mais árdua a tarefa de mergulhar na simplicidade (profunda) da obra de Villa-Lobos para canto e violão. 


\section{Referências}

ALFONSO, Sandra Mara. O Violão, da marginalidade à academia: trajetória de Jodacil Damaceno. 2. ed. Uberlândia: EDUFU, 2017.

AMARAL, Euclides. Alguns aspectos da MPB. 2. ed. Rio de Janeiro: Esteio, 2010.

AMORIM, Humberto. Heitor Villa-Lobos e o Violão. Rio de Janeiro: Academia Brasileira de Música, 2009.

Heitor Villa-Lobos: uma revisão bibliográfica e considerações sobre a produção violonística. Dissertação (Mestrado) - Universidade Federal do Estado do Rio de Janeiro, Rio de Janeiro, 2007.

ANDRADE, Oswald de. O manifesto antropófago. In: TELES, Gilberto Mendonça. Vanguarda europeia e modernismo brasileiro: apresentação e crítica dos principais manifestos vanguardistas. 3. ed. Petrópolis: Vozes; Brasília: INL, 1976.

CARVALHO, Hermínio Bello de. Villa-Lobos, uma conferência. Rio de Janeiro: Museu Villa-Lobos, 1963.

. O canto do pajé. Villa-Lobos e a música popular brasileira. Rio de Janeiro: Espaço e Tempo, 1988.

CASTELLON, Marco E. T.; BARBEITAS, Flavio T. "Brazilian guitar music": music and identity in service of a stereotyped product. In: CONGRESSO DA ANPPOM, 29., 2019, Pelotas. Anais [...]. Pelotas: 2019. p. 1-9.

DELEUZE, Gilles; GUATTARI, Félix. Mil Platôs: capitalismo e esquizofrenia. São Paulo: Ed. 34, 2000.

FOUCAULT, Michel. Arqueologia das Ciências e História dos Sistemas de Pensamento. Rio de Janeiro: Forense Universitária, 2005

GINZBURG, Carlo. O queijo e os vermes: o cotidiano e as ideias de um moleiro perseguido pela Inquisição. São Paulo: Schwarcz, 1987.

LLANOS, Carlos Fernando Elías. Nem erudito, nem popular: por uma identidade transitiva do violão brasileiro. Tese (Doutorado em Música) - Escola de Comunicações e Artes, Universidade de São Paulo, São Paulo, 2018.

PEREIRA, Fernanda M. C. O violão na sociedade carioca (1900-1930): técnicas, 
estéticas e ideologias. 2007. 127 f. Dissertação (Mestrado em Música) - Programa de Pós-Graduação em Música, Escola de Música, UFRJ, Rio de Janeiro, 2007.

TABORDA, Marcia. Violão e Identidade Nacional: Rio de Janeiro 1830-1930. Rio de Janeiro: Civilização Brasileira, 2011.

\section{Periódicos}

A NOITE. Homenagem a Villa Lobos, na A. B. I., Rio de Janeiro, Ed. 15689, 7 ago. 1957a, $2 \circ$ caderno, p. 4.

Homenagem a Villa Lobos, Rio de Janeiro, 10 ago 1957b, 1으 caderno, p. 7.

Música. Rio de Janeiro, Ed. 15678, 25 jul. 1957c, 2ํ caderno, p. 4.

Música. Rio de Janeiro, Ed. 15695, 14 ago. 1957d, 2º caderno, p. 4.

Música. Rio de Janeiro, Ed. 17072, 9 nov. 1962, p. 6.

BOLETIM DA ASSOCIAÇÃO BRASILEIRA DE IMPRENSA. Dois aspectos da homenagem da A.B.I. a Vila-Lobos, Rio de Janeiro, Ed. 65, set. 1957, p. 8.

CORREIO DA MANHÃ. Música - Villa Lobos na ABI. Rio de Janeiro, Ed. 19747, 10 ago. 1957, 1ำ caderno, p. 13.

$\neg$ ᄀ Rio de Janeiro, Ed. 19917, 2 mar. 1958, 5 caderno, p. 7.

DIÁRIO CARIOCA, Concertos, Rio de Janeiro, Ed. 10627, 8 nov. 1962a, p. 8.

A Semana Villa-Lobos, Rio de Janeiro, Ed. 10627, 8 nov. 1962b, p. 9.

Música popular, Elisete e o diálogo. Rio de Janeiro, Ed. 11247, 19 nov. 1964, p. 7.

DIÁRIO DE NOTÍCIAS. Orquestra Sinfônica Brasileira. Rio de Janeiro, Ed. 12.265, 9 nov. 1962, Segunda Seção, p. 3.

Modinhas inéditas, hoje, Rio de Janeiro, Ed. 15285, 24 ago. 1972, p 3.

Rio de Janeiro, Ed. 15447, 2 mar. 1973, p, 3.

DIÁRIO DO PARANÁ. Música, Curitiba, Ed. 5317, 25 mar. 1973, 3ํcaderno, p. 4. 
JORNAL DO BRASIL. Dos 12 aos 72 anos Vila-Lôbos [sic] compôs sua posteridade, Rio de Janeiro, Ed. 273, 22 nov. 1959, 2ำ caderno, p. 12.

Música - Os novos discos, Rio de Janeiro, Ed. 222, 21 dez. 1967, Caderno B, p.

2

A música que vai aos bairros, Rio de Janeiro, Ed. 150, 17 set. 1972, Caderno B, p. 20.

Música, Rio de Janeiro, Ed. 330, 21 mar. 1973a, Caderno B, p. 2.

Melodias brasileiras num violão internacional, Rio de Janeiro, Ed. 142, 28 ago. 1973b, p. 5.

Música, Rio de Janeiro, Ed. 218, 12 nov. 1974a, Caderno B, p. 7.

Música, Rio de Janeiro, Ed. 219, 13 nov. 1974b, Caderno B, p. 6.

. Maria Lúcia Godoy canta Villa-Lobos, Rio de Janeiro, Ed. 251, 15 dez. 1977,

Caderno B, p. 5.

Rio de Janeiro, Ed. 331, 9 mar. 1978, Caderno B, p. 8.

Vozes, violões e uma orquestra de jovens, Rio de Janeiro, Ed. 47, 25 mai. 1979, Caderno B, p. 4.

Maria Lúcia Godoy canta Villa-Lobos. Rio de Janeiro, Ed. 251, 15 dez. 1977,

Caderno B, p. 5.

B, p. 8

Uma estreia cheia de méritos. Rio de Janeiro, Ed. 278, 13 jan. 1989, Caderno

JORNAL DO COMMERCIO. Rio de Janeiro, Ed. 36, 13 nov. 1960, 2 caderno, p. 4.

Foto inédita de Villa-Lobos. Rio de Janeiro, Ed. 35, 11 nov. 1962, [Música], p. 3.

JORNAL DOS SPORTS. Rio tem concurso internacional de canto em novembro. Rio de Janeiro, Ed. 12990, 22 abril 1973, Segundo Tempo, p. 3.

O DIA. Bachianas de Villa-Lobos no violão de Jodacil Damaceno. Rio de Janeiro, n. 3, 4 dez. 1967. 
O JORNAL. Rio de Janeiro, Ed. 11.509, 19 mar. 1958, Segunda Seção, p. 3.

TRIBUNA DA IMPRENSA. Rio de Janeiro, Ed. 4787, 18 out. 1963, Segundo Caderno, p. 3. Música, Rio de Janeiro, Ed. 2080, 21 ago. 1973, p. 10.

Essa semana na Sala Cecília Meireles, Rio de Janeiro, Ed. 9062, 21 mai. 1979, p. 10.

Rio de Janeiro, Ed. 11771, 4 dez. 1987, p. 4 [Tribuna Bis, suplemento do jornal].

Rio de Janeiro, Ed. 12186, 10 abr. 1989, p. 4 [Tribuna Bis, suplemento do jornal].

A meio-soprano surpreende em canções. Rio de Janeiro, Ed. 13681, 7 dez.

1994, p. 2 [Tribuna Bis, suplemento do jornal]. 